\title{
Chapter 3 \\ The Interplay Between Investor-State Arbitration and Domestic Courts in the Existing IIA Framework
}

\subsection{Introduction}

The interrelation between investment arbitration and domestic courts is complex and versatile, varying from harmonious co-existence to reinforcing complementation, reciprocal supervision and, occasionally, competition and tension. This chapter provides an overview of the different ways in which the inter-relationship between domestic courts and investor-State arbitration occurs in the current IIA framework. It first looks at the allocation of jurisdiction over investment disputes between courts and arbitral tribunals and reviews the ways in which the current IIA framework seeks to regulate the jurisdictional interaction between domestic and international tribunals (infra at Sect. 3.2). Section 3.3 then reviews the role of national courts in support and control of investment tribunals. Finally, Sect. 3.4 provides an overview of the reciprocal scrutiny of investor-State tribunals over the conduct of domestic courts.

As already noted in the introductory remarks (supra in Chap. 1), the main points of intersection between domestic courts and international investment tribunals examined in this study touch on issues of jurisdiction, admissibility, merits, and procedure. The questions reviewed thus extend over almost all aspects of the law of investment protection, both substantive and procedural. Many of these questions are controversial and have often given rise to splits in the jurisprudence. Given the breadth of the issues, the study's approach is to focus primarily on State practice as reflected in the conclusion of IIAs and the policies underlying the choices reflected in the treaties. By contrast, the study does not systematically deal with the tools available to arbitral tribunals in seeking to coordinate multiple proceedings, e.g. lis pendens, res judicata, or abuse of process. 


\subsection{Allocation of Jurisdiction Between Investor-State Tribunals and Domestic Courts}

\subsubsection{Jurisdictional Overlaps Between National and International Courts}

58 Multiple judicial institutions, national and international, may be authorized to adjudicate-i.e. have jurisdiction over-what in substance is one and the same dispute, namely a disagreement about a State measure that has caused certain harm. These jurisdictional overlaps between domestic courts and international tribunals are not confined to investment law; they also occur in other areas of international law. ${ }^{1}$ In the field of investment law, they have, however, given rise to particular difficulties and complexities.

A few examples may illustrate the extent of the jurisdictional interactions between national courts and international tribunals in investment law. A first point of jurisdictional contact and potential tension occurs in the adjudication of contract and treaty claims. A foreign investor may enter into an investment contract with the host State or a State-owned entity to regulate the terms of its cross-border investment in the host State. That contract may be governed by a certain substantive law (often the host State's law) and, of special relevance here, contain a dispute resolution clause providing for the jurisdiction of the host State's domestic courts or for commercial arbitration with a seat in the host State.

60 In $S G S$ v. Philippines, for instance, the contract between the Swiss investor and the Philippines contained a choice in favor of the courts of the Philippines. When the Philippines failed to make certain payments under the contract, the investor filed an ICSID arbitration against the State, relying on the dispute resolution clause contained in the Swiss-Philippines BIT and alleging that the Philippines' conduct breached the BIT standards. Faced with the respondent's jurisdictional objection that the dispute was purely contractual and thus subject to the Philippines' courts in accordance with the contract, the ICSID tribunal determined that "justice would be best served if the Tribunal were to stay the [proceedings before it] pending determination of the amount payable [under the contract], either by agreement between the parties or by the Philippine courts in accordance with [the contract]". ${ }^{2}$ The SGS $v$. Pakistan dispute presented a similar situation. Here, the contract provided for domestic arbitration in Pakistan. After Pakistan had commenced contractual arbitration in Islamabad, SGS filed an ICSID arbitration under the Swiss-Pakistan BIT. Pakistan argued that SGS's claim was essentially a claim for breach of contract, which should be submitted to the exclusive jurisdiction of the arbitrator in Pakistan. The ICSID tribunal found that the forum selection clause in the contract did not

\footnotetext{
${ }^{1}$ See generally Shany (2007).

${ }^{2}$ See SGS Société Générale de Surveillance S.A. v. Republic of the Philippines, ICSID Case No. ARB/02/6, 29 January 2004, para. 175.
} 
affect its jurisdiction to adjudicate treaty breaches based on the BIT. ${ }^{3}$ These examples show the concurrent jurisdiction of domestic courts or commercial arbitral tribunals under the contract, on the one side, and investment treaty tribunals under the treaty on the other, when both categories of adjudicatory bodies are seized of claims that arise out of substantively the same State conduct.

In a second type of overlapping situation, a foreign investor may seek to vindicate its rights for the same allegedly wrongful conduct by the State under both an IIA and domestic administrative or constitutional law. In the dispute between the Swedish State-owned company Vattenfall and the Federal Republic of Germany arising out of the State's decision to phase out nuclear energy after Fukushima, for instance, Vattenfall brought an ICSID arbitration against Germany under the ECT, which is still pending at the time of writing. ${ }^{4}$ At the same time, Vattenfall's German subsidiary brought a constitutional complaint (Verfassungsbeschwerde) before the Federal Constitutional Court of Germany (Bundesverfassungsgericht) alleging that the closure of nuclear plants was tantamount to expropriation and that the lack of compensation for the nuclear phase-out required by the German Atomic Energy Act was inconsistent with German constitutional law. In 2016, the German Constitutional Court held that the German legislative measures were "for the most part compatible with the Basic Law" (the German constitution or Grundgesetz) and did not amount to an expropriation, while certain restrictions contained in the law were contrary to the constitutional right to property as they did not provide for compensation. ${ }^{5}$

In Spain, the changes to the regulatory framework in the solar (photovoltaic) energy sector effected through a series of regulatory and legislative measures enacted between 2010 and 2013 triggered a wave of investor-State arbitrations brought by foreign investors against the Kingdom of Spain under the ECT and have resulted, in certain instances, in findings of liability against the Government. ${ }^{6}$ At the same time, investors and other actors complained that the same measures were contrary to Spanish administrative and constitutional law and seized both the Spanish Supreme Court (Tribunal Supremo) and Constitutional Court (Tribunal Constitucional). ${ }^{7}$ Both the investment treaty tribunals and the Spanish courts have thus passed judgment on claims for alleged violations of similar principles of legal certainty and legitimate expectations. These principles were anchored, however, in

\footnotetext{
${ }^{3}$ See SGS Société Générale de Surveillance S.A. v. Islamic Republic of Pakistan, ICSID Case No. ARB/01/13, Decision of the Tribunal on Objections to Jurisdiction, 6 August 2003. The tribunal found, however, that it did not have jurisdiction over purely contractual claims which did not also amount to breaches of the relevant BIT.

${ }^{4}$ See Vattenfall $A B$ and others v. Federal Republic of Germany, ICSID Case No. ARB/12/12 (pending).

${ }^{5}$ See German Federal Constitutional Court, Judgment of the First Senate of 6 December 2016, 1 BvR 2821/11 (German version available at http://www.bverfg.de/e/rs20161206_1bvr282111. $\mathrm{html}$ and English version available at http://www.bverfg.de/e/rs20161206_1bvr282111en.html).

${ }^{6}$ See, e.g., Eiser Infrastructure Limited and Energía Solar Luxembourg S.à r.l. v. Kingdom of Spain, ICSID Case No. ARB/13/36, Final Award, 7 May 2017.

${ }^{7}$ See generally García-Castrillón (2016).
} 
different legal regimes, namely international law, specifically an IIA, for the investment claims and domestic law, specifically administrative and constitutional law, for the domestic claims. ${ }^{8}$ In an analogous fashion, Italy's and the Czech Republic's repeal of incentives granted to renewable energy operators gave rise to both domestic and investment treaty arbitrations. It appears that in the Italian domestic proceedings, petitioners asserted violations not only of Italian administrative and constitutional law, but also of international law, including the ECT and the ECHR. ${ }^{9}$

These few examples show that a State measure or conduct may potentially violate several sources of laws, each with its own system of remedies, and thus potentially open up multiple avenues for redress to aggrieved investors. As a result, international arbitral tribunals routinely examine domestic measures adopted by national governments under investment law standards, while national courts may review those same measures from the perspective of domestic constitutional, administrative, tax or civil law (and, less frequently, also from the perspective of international law if the latter can be directly invoked by private parties before domestic courts). ${ }^{10}$ Cases before the national and international courts are not always brought by the same party, but may be pursued by closely related parties (such as shareholders, subsidiaries, parent companies, etc.), either consecutively or simultaneously.

Despite the fact that the disputes brought before these different fora are distinct and formally independent, because the parties are often non-identical, the "cause of action" or legal basis for the claims is different (domestic law v. IIA), and the remedies sought may be distinct (annulment of a regulation, declaration of constitutionality, monetary compensation), the essence of the dispute is often the same in that it bears on the same set of facts or measures and involves the same economic harm. In practice, the multiplicity of remedies poses potential problems of duplication of proceedings, which implies a waste of resources, risks of conflicting factual and legal determinations, and risks of double or multiple recovery, where compensation is an available remedy in the different sets of proceedings.

It should also not be overlooked that when State measures negatively affect an investment, in addition to investment arbitration based on an IIA, private parties may be entitled to bring a claim before a human rights court (e.g., the ECtHR) alleging the violation of human rights, in particular—as far as relevant here-the right to

\footnotetext{
${ }^{8}$ In certain of the Spanish domestic cases, the ECT was also invoked. See García-Castrillón (2016), pp. 6-7 (discussing the judgment of the Spanish Constitutional Court no. 270/2015, in which the petitioners also invoked provisions of the ECT).

${ }^{9}$ See Greentech Energy Systems A/S, et al v. Italian Republic, SCC Case No. V 2015/095, Final Award, 23 December 2018, para. 197 (where Italy argued that "several Italian administrative court actions were brought by parties [...] regarding the measures at issue in this arbitration" and that "claimants in those actions asserted violations of the Italian Constitution, the ECHR, the ECT, and certain EU directives"). With regard to the Czech measures in the renewable energy sector which gave rise to both domestic and investment treaty arbitrations, see, e.g., Jürgen Wirtgen, Stefan Wirtgen, Gisela Wirtgen and JSW Solar (zwei) GmbH \& Co. KG v. Czech Republic, PCA Case No. 2014-03, Final Award, 11 October 2017, sections II.G, V.D(1)(h) and (2)(h).

${ }^{10}$ See the Spanish and Italian cases mentioned supra at the preceding footnotes and the discussion infra at Sect. 3.2.2.1.
} 
property under Protocol 1 of the ECHR. In Yukos v. Russia, for instance, the claimants in the ECT investment arbitrations and/or certain related parties brought domestic actions before the Russian courts as well as proceedings in the ECtHR. ${ }^{11}$

Against this background of multiple litigation opportunities, how does the IIA framework deal with the competing jurisdiction of national and international courts over the same dispute (understood in substantive terms) concerning an investment? As will be seen from the following sub-sections, IIAs seek to regulate the allocation of jurisdiction between domestic courts and investment treaty arbitration in two broad ways. The treaty may offer a choice between domestic courts and international arbitration ("alternative" approach) (infra at Sect. 3.2.2) or it may require that domestic remedies be pursued or even exhausted prior to commencing arbitration proceedings ("sequential" approach) (infra at Sect. 3.2.3). Within those broad categories, States have devised several constellations to cater for different policy concerns. Despite a growing awareness of the jurisdictional overlaps between national and international courts, the rules contained in IIAs do not always appear satisfactory. Indeed, they do not always provide for a clear "division of labor" between domestic courts and international tribunals; often they do not cater for the fact that the legal basis and the parties in the two settings may not be the same; and do not clarify whether one forum may (or even must) consider its counterpart's decision, ultimately leaving these matters to the best judgment of courts and tribunals.

\subsubsection{Domestic Courts and International Arbitration as Alternative Fora}

IIAs often offer investors an alternative between domestic courts and international investment arbitration. Among other issues, this option raises the question of whether IIAs can be directly invoked by investors before domestic courts (infra at Sect. 3.2.2.1). Furthermore, where the investor has the choice of submitting its investment dispute before the domestic courts or in international arbitration, some

\footnotetext{
${ }^{11}$ See Yukos Universal Limited (Isle of Man) v. The Russian Federation, UNCITRAL, PCA Case No. AA 227, Interim Award on Jurisdiction and Admissibility, 30 November 2009, paras. 587-600. The same measures may also be concurrently reviewed in domestic courts, investment treaty arbitration, and in the inter-State WTO setting. See, for instance, the tobacco restriction measures implemented in Australia, which gave rise to both domestic court proceedings (JT International SA v. Commonwealth of Australia British American Tobacco Australasia Limited v. The Commonwealth [2012] High Court of Australia 43), investment treaty arbitration (Philip Morris Asia Limited v. The Commonwealth of Australia, UNCITRAL, PCA Case No. 2012-12, Notice of Arbitration, 22 June 2011), and WTO disputes (Australia-Certain Measures Concerning Trademarks and Other Plain Packaging Requirements Applicable to Tobacco Products and Packaging, WT/DS434,WT/DS435,WT/DS441 (complaints initiated by the Dominican Republic, Honduras, and Ukraine on 18 July 2012, 4 April 2012, and 13 March 2012, respectively)). On jurisdictional overlaps between investment treaty and WTO disputes, see Allen and Soave (2014), pp. 1-58.
} 
IIAs seek to minimize the risk of duplication of proceedings through fork-in-theroad or waiver clauses (infra at Sect. 3.2.2.2).

\subsubsection{Domestic Courts as a Possible Forum for Disputes Under the IIA?}

68 Regardless of whether an IIA mentions the host State's domestic courts as a forum for the adjudication of investment disputes between investors and States, those courts would normally be the default forum. Indeed, under usual choice of court rules, the proper forum would be that of the defendant, i.e. the host State, which also happens to be the place where the investment was made. ${ }^{12}$ In fact, although there are no precise figures in this respect, ${ }^{13}$ many disputes relating to an investment are resolved before domestic courts by reference to domestic law standards. Where the investor has the option of taking up an arbitration offer contained in an investment treaty, absent other direct arrangements with the State (e.g., an arbitration clause in a contract) the investor remains free to seize the domestic courts of its investment dispute, until it has taken up that offer. When it accepts the offer and consent to arbitration is perfected, limitations to bring the dispute before domestic courts may come into play depending on the applicable legal framework, for instance as a result of Article 26 of the ICSID Convention (which provides that "[c]onsent of the parties to arbitration under this Convention shall, unless otherwise stated, be deemed consent to such arbitration to the exclusion of any other remedy"), or of provisions contained in an IIA, such as a fork-in-the road or waiver clause (on which see infra at Sect. 3.2.2.2).

69 It is not uncommon for IIAs to mention expressly that domestic courts are a possible forum alternative to the international arbitration options provided under the treaty. The Switzerland-Tajikistan BIT (2009), for instance, provides that in respect of a "dispute with respect to investments between a Contracting Party and an investor of the other Contracting Party", "the investor may submit the dispute either to the national jurisdiction of the Contracting Party in whose territory the investment was made or to international arbitration". 14 Other IIAs provide that disputes "concerning an obligation under the treaty" (or similar formulations) can be brought before domestic courts or international arbitration. As an example, the SwitzerlandTrinidad and Tobago BIT (2010) sets out that "the investor may submit the dispute [concerning an obligation under this Agreement] either to the courts or the administrative tribunals of the Contracting Party in whose territory the investment has been made or to international arbitration". ${ }^{15}$

\footnotetext{
${ }^{12}$ See Dolzer and Schreuer (2012), p. 235.

${ }^{13}$ See the discussion in Bonnitcha et al. (2017), p. 82.

${ }^{14}$ See Switzerland-Tajikistan BIT (2009), Article 11, paras. 1-2.

${ }^{15}$ Switzerland-Trinidad and Tobago BIT (2010), Article 8, para. 2.
} 
In respect of these IIA formulations presenting domestic courts and investment treaty tribunals as adjudicative alternatives, the question arises whether an investor may invoke the substantive standards contained in the IIA before the local courts, rather than merely litigate its dispute by application of domestic law. ${ }^{16}$ Whether there is scope for the application of IIAs by domestic courts depends on the text of the treaty and each domestic legal system.

Treaties (or the domestic instruments accompanying their ratification) ${ }^{17}$ rarely specify their own domestic law effects. ${ }^{18}$ The answer to the question of whether the provisions of an IIA can be relied upon by private parties before domestic courts (or,

\footnotetext{
${ }^{16}$ Examples of direct application of IIAs (or their "predecessors", the friendship, commerce, and navigation (FCN) treaties) before domestic courts of some countries have been documented, though they are not frequent. See Kjos (2016), pp. 81-96. See also Elettronica Sicula S.p.A. (ELSI) (Italy v. U.S.), Judgment, 1989 I.C.J. Rep. 15, 28 I.L.M. 1109 (July 20), paras. 61-62, where the chamber of the ICJ addresses Italy's position that individuals had been able to invoke provisions of FCN treaties before the Italian courts. See also supra Chap. 3, footnotes 8 and 9.

${ }^{17}$ See, e.g., U.S.-Rwanda BIT (2008), in which the U.S. Senate's report contains the following statements: "The resolution of advice and consent contains a statement reflecting the committee's understanding of the extent to which this Treaty will be self-executing. This provides that Articles 3-10 of the Treaty are self-executing and do not confer private rights of action enforceable in United States courts." (emphasis added). U.S. Congress, Investment Treaty With Rwanda, Senate Exec. Report 112-2, 12th Congress, 1st Session, 2 August 2011, 11 available at https://www. foreign.senate.gov/imo/media/doc/110-23.pdf. See also ibid., 14 the "Text of Resolution of Advice and Consent to Ratification" at Title VII, Section 2, last sentence whereby "[n]one of the provisions in this Treaty confers a private right of action". A further example can be seen in the U.S.-Australia FTA (2004), which does not provide for investment arbitration, but merely State-to-State dispute settlement, and for which the U.S. implementing legislation provides that "[n]o person other than the United States [...] shall have any cause of action or defense under the Agreement [...] or may challenge $[\ldots]$ any action or inaction by any department, agency, or other instrumentality of the United States, any State, or any political subdivision of a State, on the ground that such action or inaction is inconsistent with the Agreement". See United States-Australia Free Trade Agreement Implementation Act, Public Law No 108-286, Sections 102(c)(1)-(2), 118 Statute 919 (2004) (codified at 19 USC section 3805 note). The U.S.-Australia FTA (2004) thereby entails that the substantive standards of protection can only be invoked in a State-to-State diplomatic protection scenario and not before the domestic courts, as noted by Dodge (2006), pp. 25-26.

In the context of the ECT, Article 26, paras. 1-2, provides that the investor has the choice to submit disputes "which concern an alleged breach of an obligation of the [host Contracting Party] under Part III" of the ECT "(a) to the courts or administrative tribunals of the Contracting Party party to the dispute". This provision of the ECT is accompanied by an "Understanding no. 16" whereby "Article 26(2)(a) should not be interpreted to require a Contracting Party to enact Part III of the Treaty into its domestic law". See generally on this De Luca (2016), available at http://rivista. eurojus.it/direct-effect-of-eus-investment-agreements-and-the-energy-charter-treaty-in-the-eu/ (arguing that "Understanding 16 seems to assume that Part III has direct effect within the domestic legal systems of the Contracting Parties, rather than the opposite").

${ }^{18}$ See Bronckers (2015), pp. 662-664. However see, for instance, CETA, providing that "[n]othing in this Agreement shall be construed as [...] permitting this Agreement to be directly invoked in the domestic legal systems of the Parties" (Article 30.6.1) and that "[a] Party shall not provide for a right of action under its domestic law against the other Party on the ground that a measure of the other Party is inconsistent with this Agreement" (Article 30.6.2). Consistent with this approach, the dispute settlement provisions in the investment chapter of the treaty provide that the investor may
} 
in the parlance of certain jurisdictions, whether the treaty provides for a "private right of action" or "private cause of action" before the local courts) is thus left to the legal systems of each treaty party. ${ }^{19}$

In the United States, for instance, the U.S. Supreme Court has held that "[e]ven when treaties are self-executing in the sense that they create federal law, the background presumption is that '[i]nternational agreements, even those directly benefiting private persons, generally do not create private rights or provide for a private cause of action in domestic courts". ${ }^{20}$ Based on this holding, certain U.S. courts have concluded that a private party has no "standing to sue under the treaty" where the treaty in question had "no express language to rebut a presumption against a private right of action". ${ }^{21}$

73 Courts of other States, including Switzerland, have resorted to a number of criteria to determine whether provisions in a treaty can be directly invoked by individuals before the domestic courts. The Swiss Federal Tribunal, for instance, requires the provision at issue to be "sufficiently clear and precise so as to serve as the basis of a decision in a specific case", and "susceptible of application in court"; be concerned with "rights and obligations of private parties"; and "be addressed to the authorities charged with the application of the law" rather than the legislator. ${ }^{22}$

If an IIA were to be invoked before the Swiss courts, it would seem that the very fact that the treaty affords the investor an option to file its treaty claims in the domestic courts of the host State in and of itself implies that the treaty standards are susceptible of being applied by a court, regardless of the criteria just referred to. A contrary conclusion would be difficult to reconcile with the State's undertaking in

only bring a claim for alleged breaches of the CETA investment protection standards before the international tribunal constituted under the treaty, and not before domestic courts.

${ }^{19}$ The question as to whether an individual may invoke a treaty before domestic courts should be distinguished from the so-called "self-executing" nature of treaties (i.e., treaties that create a legal obligation in the absence of implementing legislation). See Hathaway et al. (2012), p. 56, also referring to Restatement (Third) of Foreign Relations, section $111 \mathrm{cmt}$. G (1987) (whereby "[w]hether a treaty is self-executing is a question distinct from whether the treaty creates private rights or remedies"). See also Kaiser (2013), paras. 1-3.

${ }^{20}$ Medellin v. Texas, 522 US 491 (2008).

${ }^{21}$ See Hathaway et al. (2012), pp. 70-76 (discussing U.S. cases applying treaties, including FCN treaties, after the Supreme Court case in Medellin, quoted above in the text).

${ }^{22}$ See, e.g., Swiss Federal Tribunal, L.X. v. M.F, decision of 22 December 1997, 90, 91, para. 3 (a) (a provision in a treaty must be regarded as directly applicable "wenn die Bestimmung inhaltlich hinreichend bestimmt und klar ist, um im Einzelfall Grundlage eines Entscheides zu bilden; die Norm muss mithin justiziabel sein, die Rechte und Pflichten des Einzelnen zum Inhalt haben, und Adressat der Norm müssen die rechtsanwendenden Behörden sein"/“Pour qu'une règle soit directement applicable, il faut que le contenu de la disposition en cause soit suffisamment clair et précis pour servir de fondement à une décision d'espèce. La règle doit donc être susceptible d'application sur le plan judiciaire, porter sur des droits et des devoirs particuliers et s'adresser aux autorités chargées de l'application du droit"). See also Swiss Federal Tribunal, D. $v$. Familienausgleichskasse Zug, decision of 31 August 2010, 297, 307-308, para. 8.1; Swiss Federal Tribunal, Schmid und Mitb. v. Regierungsrat und Grossen Rat des Kantons Basel-Stadt, decision of 7 August 2007, 286, 291, para. 3.2. See generally, Besson (2016), pp. 333-337. 
the treaty "that the investor may submit the dispute concerning an obligation under the IIA either to the courts of the Contracting Party in whose territory the investment has been made or to international arbitration". It would also be astonishing that domestic courts could not apply treaty standards, for instance because they would be regarded as insufficiently clear or precise, when the same standards are expected to be applied - and are routinely applied-by arbitral tribunals. Because of the very nature of IIAs, which confer rights on private parties and impose obligations on States vis-à-vis these private parties, the same solution should prevail, i.e. domestic courts should be in a position to apply the IIA, even when the treaty does not expressly provide for the possibility to submit claims arising out of the treaty to national courts.

\subsubsection{Fork-in-the-Road and Waiver Clauses}

IIAs may seek to coordinate domestic and international proceedings in respect of the same investment dispute through so-called "fork-in-the-road" clauses and "waiver"/ "no U-turn" provisions. ${ }^{23}$

Through a fork-in-the-road clause, States wish to make sure that, where the investor has a choice between domestic courts and international arbitration, the investor's choice once made is final. In other words, if the fork-in-the-road is triggered, the investor may only continue to pursue its claim in the forum to which it has first turned (electa una via, non datur recursus ad alteram). ${ }^{24}$ In still other words, once the choice is made, the alternative forum becomes exclusive.

Fork-in-the-road clauses may entail different consequences depending on their wording. Some may make the choice of either domestic courts or international arbitration irreversible, whatever forum is seized first. The Switzerland-Colombia BIT, for instance, provides that "[o]nce the investor has referred the dispute to either a national tribunal or any of the international arbitration mechanisms provided for in paragraph 2 above, the choice of the procedure shall be final". ${ }^{25}$ Other treaties prescribe that only the choice of domestic courts is final. ${ }^{26}$ Alternatively, the investor's choice between international arbitration and domestic court proceedings

\footnotetext{
${ }^{23}$ Some BITs, however, provide that the investor can access domestic courts and investment arbitration one after the other. See Germany-Madagascar BIT (2006), Article 11, para. 2.

${ }^{24}$ Schreuer (2004), pp. 239-240.

${ }^{25}$ Switzerland-Colombia BIT (2006), Article 11, para. 4. See also Switzerland-Egypt BIT (2010), Article 12, para. 6, ("Once the investor has submitted the investment dispute to one of the fora referred to in paragraph (3), that election is final").

${ }^{26}$ See, e.g., Switzerland-Saudi Arabia BIT (2006), Article 10, para. 3 (providing that "[i]f the dispute has been filed with the competent court of the Contracting Party in accordance with paragraph (2) of this Article, the investor may not submit this dispute to international arbitration as referred to in the same paragraph").
} 
may be reversible until the first instance domestic court has issued its judgment, but not later. ${ }^{27}$

The ECT provides for a choice of several fora, including domestic courts and international arbitration. The treaty offers the Contracting Parties the possibility to opt into the fork-in-the-road clause pursuant to Article 26, para. 3(b)(i), and, specifically, to limit their consent to international arbitration only to disputes which the investor has not previously submitted to the domestic courts (or other previously agreed dispute settlement procedure). A number of Contracting Parties, including the European Union, some of its Member States, and Japan, have availed themselves of this possibility and provided written statements under Article 26, para. 3(b)(ii) of their "policies, practices and conditions" in respect of the application of the fork-in-the-road clause. ${ }^{28}$ With regard to States such as Switzerland who have made no such statement under Article 26, para. 3(b)(ii), the investor's prior initiation of domestic court proceedings does not prevent the investor from subsequently launching an international arbitration against that State. ${ }^{29}$

A different type of approach to the coordination of multiple proceedings before domestic and international fora is to include "waiver" or "no-U-turn" clauses. Unlike fork-in-the-road clauses (which make the choice of forum by the investor final), waiver or no-U-turn provisions permit investors to opt for international arbitration after commencing domestic court proceedings in relation to the same measure. However, if the investor decides to submit a claim to international arbitration

\footnotetext{
${ }^{27}$ See, e.g., Austria-Slovenia BIT (2001), Article 11, para. 4 (providing that "[t]he investor may choose to submit the dispute for resolution according to paragraph $2 \mathrm{~b}$ [international arbitration] only until there has been a decision concerning the same claim in the first instance in the proceedings according to paragraph 2a [domestic courts]"); Austria-Mexico BIT (1998), Article 10, para. 2 (providing that "[i]f an investor of a Contracting Party or his investment that is an enterprise initiates proceedings before a national tribunal with respect to a measure that is alleged to be a breach of this Agreement, the dispute may only be submitted to arbitration under this Part if the competent national tribunal has not rendered judgment in the first instance on the merits of the case"). Similarly, the Switzerland-Turkey BIT (1988) appears to entitle the investor to initiate ICSID arbitration as long as the domestic court has not issued a final decision. See SwitzerlandTurkey BIT (1988), Article 8, para. 3 (providing that "the dispute shall be submitted to [ICSID arbitration] [...], provided that in case the investor concerned has brought the dispute before the courts of justice of the Contracting Party that is a party to the dispute and there has not been rendered a final award [sic]").

${ }^{28}$ See Energy Charter Secretariat, "Transparency Document: Policies, Practices And Conditions Of Contracting Parties Listed In Annex ID Not Allowing an Investor to Resubmit the Same Dispute to International Arbitration at a Later Stage As Provided By Contracting Parties (in accordance with Article 26(3)(b)(ii) of the Energy Charter Treaty)", 10 June 2009, available at https://www. energychartertreaty.org/fileadmin/DocumentsMedia/Founding_Docs/June_2009_Annex_ID.pdf.

${ }^{29}$ See, e.g., Petrobart Ltd v. Kyrgyz Republic, SCC Case No 126/ 2003, Arbitral Award, 29 March 2005, p. 56 (noting that "even if Petrobart had submitted its claims based on the Treaty to any of the above fora (i.e. domestic court or UNCITRAL arbitration), which it did not, subsequent submission to arbitration under Article 26 would still have been permissible. This would have been the case because [...] the Kyrgyz Republic chose not to be listed in Annex ID of the Treaty").
} 
under the dispute settlement provision in the IIA, it is required to discontinue domestic court proceedings or waive its right to start new such proceedings.

This type of provisions is typically contained in IIAs entered into by the U.S. ${ }^{30}$ The Switzerland-China BIT also provides that "[a] dispute that has been submitted, in accordance with paragraph (2), to a competent court of the Contracting Party concerned, may only be submitted to international arbitration after withdrawal by the investor of the case from the domestic court". ${ }^{31}$

In broad terms, fork-in-the-road and waiver clauses pursue the same objectives: avoiding parallel proceedings, which entail duplication of costs, risks of double recovery and of inconsistent outcomes. Despite their common goals, the two types of clauses imply somewhat different policies and entail advantages and disadvantages. Fork-in-the-road clauses are aimed at avoiding that a dispute is litigated first before domestic courts, and then before an international tribunal (or vice versa). Their effect is to prevent, in principle, any duplication of proceedings and thus of costs, because the trigger of one forum automatically entails the loss of access to the other. They may, however, prompt investors to immediately access the international forum, for fear of otherwise losing that option if domestic proceedings are started. Waiver clauses, on the other hand, do not pre-empt nor discourage investors from seeking redress before national courts first, as they leave the investors' right to access the international forum intact, if for instance the domestic proceedings are deemed unsatisfactory. This may entail a waste of resources if domestic courts are accessed first and then those proceedings are discontinued once arbitration proceedings are commenced. However, because domestic court proceedings may lead to a satisfactory outcome of the dispute, waiver clauses may have the effect of reducing potential investment arbitration claims.

The interpretation of fork-in-the-road and waiver clauses has occupied arbitral tribunals who have been faced with numerous questions concerning their scope of application. In particular, questions as to whether identity is required between parties, object, and cause of action (so-called "triple identity test" transposed from res judicata and lis pendens requirements) in the domestic and international

\footnotetext{
${ }^{30}$ U.S.-CAFTA-DR (2004), Article 10.18, para. 2(b), for instance, requires the investor's notice of arbitration to be accompanied by a "written waiver" "of any right to initiate or continue before any administrative tribunal or court under the law of any Party, or other dispute settlement procedures, any proceeding with respect to any measure alleged to constitute a breach referred to in Article $10.16 "$ ".

${ }^{31}$ Switzerland-China BIT (2009), Article 11, para. 4. See also Switzerland-Japan FTA (2009), Chapter 9, Article 94, para. 6(b). Sometimes, fork-in-the-road or waiver clauses specify that, regardless of the choice that the investor makes between one or the other forum, the investor is not prevented from applying to the host State's courts for provisional measures. See, e.g., Switzerland-Japan FTA (2009), Chapter 9, Article 94, para. 6, second sentence ("It is understood that a disputing investor may initiate or continue an action that seeks interim injunctive relief and does not involve the payment of monetary damages before a judicial or administrative tribunal of the disputing Party, provided that the action is brought for the sole purpose of preserving the disputing investor's rights and interests while the conciliation or arbitration is pending").
} 
proceedings, have been invariably raised in investment jurisprudence. ${ }^{32}$ The supposed requirement for an identity of cause of action has proven particularly problematic where the claims under the treaty were linked to contractual claims that had been made before domestic courts. ${ }^{33}$

83 A careful drafting of the clauses may clarify to the benefit of investors and States a number of uncertainties that have emerged in arbitral practice. ${ }^{34}$ In particular, States may wish to consider the need to phrase fork-in-the-road and waiver clauses in broader terms than are currently provided in many IIAs, so as to cover concurrent or subsequent litigation by closely related parties (thus: not limited to the "same" party) in relation to the same facts or measures (thus: without regard to the legal basis invoked, which is often necessarily different in the two fora), aimed at achieving comparable remedies. In other words, the IIA language should aim at avoiding the limitations resulting from the application of the (too) narrow "triple identity" test, to the extent those limitations are considered inapposite. Furthermore, if States consider it appropriate, rules on coordination may extend beyond regulating domestic court and investment arbitration proceedings and cover overlaps with other international dispute settlement mechanisms providing for direct remedies to private parties (e.g., human right courts). ${ }^{35}$ Many of the waiver clauses contained in U.S. treaties

\footnotetext{
${ }^{32}$ This is not the place to do justice to the copious jurisprudence. See generally Schreuer (2004), pp. 239-249; Wegen and Markert (2010), pp. 269-292.

${ }^{33}$ See, in particular, Compañiá de Aguas del Aconquija S.A. and Vivendi Universal S.A. v. Argentine Republic, 5 ICSID Reports 299, Award, 21 November 2000, paras. 55 and 81; Compañiá de Aguas del Aconquija S.A. and Vivendi Universal S.A. v. Argentine Republic, 6 ICSID Reports 340, Decision on Annulment, 3 July 2002, paras. 36-42, 55 and 113; Alex Genin, Eastern Credit Limited, Inc. and A.S. Baltoil v. The Republic of Estonia, ICSID Case No. ARB/99/2, Award, 25 June 2001, paras. 331-332; Supervision y Control S.A. v. Republic of Costa Rica, ICSID Case No. ARB/12/4, Final Award, 18 January 2017, paras. 308-321 and 330; Yuri Bogdanov and Yulia Bogdanova v. Republic of Moldova, SCC Case No V091/2012, Final Award, 16 April 2013, paras. 173-174; Middle East Cement Shipping and Handling Co SA v. Arab Republic of Egypt, ICSID Case No ARB/99/6, Award, 12 April 2002, para. 71; Total SA v. Argentine Republic, ICSID Case No ARB/04/01, Decision on Liability, 27 December 2010, para. 443; Toto Costruzioni Generali SpA v. Republic of Lebanon, ICSID Case No. ARB/07/12, Decision on Jurisdiction, 11 September 2009, paras. 211-212; Occidental Exploration and Production Company v. Republic of Ecuador, LCIA Case No UN3467, Final Award, 1 July 2004, paras. 57-58; Pantechniki SA Contractors and Engineers v. Albania, Award, ICSID Case No ARB/07/21, IIC 38328 July 2009, paras. 61-64; $H \& H$ Enterprises Investments, Inc. v. Egypt, ICSID Case No. ARB/09/15, Award, 6 May 2014, paras. 356-382; See also Woodruff Case, IX RIAA 213, Venez. Mixed Claims Commission, 17 February 1903, pp. 222-223 (where the "fundamental basis" test was first articulated). See also Wegen and Markert (2010), p. 276.

${ }^{34}$ See for instance the recent EU-Viet Nam Investment Protection Agreement (2019) (not yet in force), Article 3.34; EU-Singapore Investment Protection Agreement (2018) (not yet in force), Article 3.7, paras. 1(f) and 2.

${ }^{35} \mathrm{By}$ contrast, as explained by Allen and Soave, it is not possible to provide for fork-in-the-road clauses that govern WTO and investment claims arising out of the same measure, because "there is no 'fork-in-the-road' for either the home State or its investor to take. An investor cannot choose a WTO claim over an investment claim, or vice versa. The investor has no control over whether a State or group of States pursues a WTO claim with respect to the same measure. Nor does the home
} 
already contain language that obliges the relevant party to waive or discontinue proceedings "with respect to the measure" not only "before any administrative tribunal or court under the law of any Party" but also before "other dispute settlement procedures". 36

\subsubsection{Prior Recourse to Domestic Courts Before Resorting to Investment Arbitration}

A number of treaties coordinate domestic and international remedies through a "sequential" approach, by requiring investors to seize domestic courts before accessing the international forum. IIAs may incorporate the traditional exhaustion of local remedies requirement (infra at Sect. 3.2.3.1) or contain prior domestic litigation requirements short of exhaustion (infra at Sect. 3.2.3.2).

\subsubsection{Exhaustion of Domestic Remedies}

Within the field of diplomatic protection, a State "may not bring an international claim in respect of an injury to a national [...] before the injured person has [...] exhausted all local remedies". ${ }^{37}$ Various justifications have been given for the rule. ${ }^{38}$ In the Interhandel case, the ICJ observed that the rule serves to ensure that "the State where the violation occurred should have an opportunity to redress it by its own means, within the framework of its own domestic system". 39

The rule requires the investor to exhaust any reasonably available remedy before administrative or judicial courts so long as the remedy is not "obviously futile". 40 This normally means obtaining the final judgment of the highest court of the host

State have control over the investor's decision to assert an investment claim". See Allen and Soave (2014), p. 54.

${ }^{36}$ See, e.g., NAFTA, Article 1121, subsections (1)(b) and (2)(b); U.S.-CAFTA-DR (2004), Article 10.18, para. (2)(b).

${ }^{37}$ International Law Commission (2006), Draft Articles on Diplomatic Protection, Official Records of the General Assembly, Sixty-first Session, Supplement No. 10, UN Doc. A/61/10, Article 14(1).

${ }^{38}$ See Crawford and Grant (2007), para. 7.

${ }^{39}$ Interhandel (Switz. v. U.S.), Preliminary Objections, 1959 I.C.J. Rep. 6, (Mar. 21 ) p. 27.

${ }^{40}$ Finnish Shipowners (Finland) v. Great Britain (Use of Certain Finish Vessels during the War) (9 May 1934), III UNRIAA, 1479, pp. 1503-1505; International Law Commission (2006), Draft Articles on Diplomatic Protection, Official Records of the General Assembly, Sixty-first Session, Supplement No. 10, UN Doc. A/61/10, Article 15; Certain Norwegian Loans (France v. Norway), Judgment, 1957 I.C.J. Rep 9, (July 6), (separate opinion of Judge Lauterpacht), pp. 39-41. 
State. ${ }^{41}$ In order to satisfy the exhaustion of local remedies requirement, the domestic and international proceedings should be "designed to obtain the same result". 42 The form and the arguments of the claims before the domestic and international tribunal may be different, as long as "the essence of the claim has been brought before the competent tribunals and pursued as far as permitted by local law and procedures, and without success". 43

87 In addition to the field of diplomatic protection, including inter-State claims under FCN treaties, ${ }^{44}$ the rule continues to be applied to individual complaints of international human rights violations. ${ }^{45}$

88 The rise of IIAs has changed considerably the role of the exhaustion of local remedies rule in investment protection claims. Because IIAs and their dispute settlement rules provide for a direct right of the investor to bring claims against the host State, they are considered to "abandon or relax the conditions relating to the exercise of diplomatic protection, particularly the rules relating to [...] the exhaustion of local remedies". ${ }^{46}$ As noted in the ILC Draft Articles on Diplomatic Protection, the rules on diplomatic protection do not apply "to the extent they are inconsistent with special rules of international law, such as treaty provisions for the protection of investments". 47

89 Within the framework of the ICSID Convention, Article 26 of the Convention provides that:

Consent of the parties to arbitration under this Convention shall, unless otherwise stated, be deemed consent to such arbitration to the exclusion of any other remedy. A Contracting State

\footnotetext{
${ }^{41}$ International Law Commission (2006), Draft Articles on Diplomatic Protection with commentaries, Report of the Fifty-Eighth Session, UN Doc. A/61/10, 2006/II(2) ILC Yearbook, Commentary to Article 14, para. 4.

${ }^{42}$ Interhandel (Switz. v. U.S.), Preliminary Objections, 1959 I.C.J. Rep. 6, (Mar. 21), p. 27.

${ }^{43}$ Elettronica Sicula S.p.A. (ELSI) (Italy v. U.S.), Judgment, 1989 I.C.J. Rep. 15, (July 20), para. 59.

${ }^{44}$ In the ELSI case before the ICJ, brought under the United States-Italy FCN treaty, the United States argued that the exhaustion of local remedies rule did not apply as it was not mentioned in the dispute settlement provision of the FCN Treaty. The ICJ found itself "unable to accept that an important principle of customary international law should be held to have been tacitly dispensed with, in the absence of any words making clear an intention to do so". See Elettronica Sicula S.p.A. (ELSI) (Italy v. U.S.), Judgment, 1989 I.C.J. Rep. 15, (July 20), para. 50.

${ }^{45}$ See International Covenant on Civil and Political Rights, (19 December 1966), 999 U.N.T.S. 171, Article 41, para. 1(c); Optional Protocol to the International Covenant on Civil and Political Rights, (19 December 1966), 999 U.N.T.S. 302, Article 5, para. 2(b); Convention for the Protection of Human Rights and Fundamental Freedoms (4 November 1950), 213 U.N.T.S. 221, Article 35, para. 1; American Convention on Human Rights, (22 November 1969), O.A.S.T.S. No. 36, Article 46, para. 1(a)-(b), 2; African (Banjul) Charter on Human and Peoples' Rights, (27 June 1981), O.A.U. Doc. No. CAB/LEG/67/3 rev. 5, 21 I.L.M. 58 (1982), Article 50.

${ }^{46}$ International Law Commission (2006), Draft Articles on Diplomatic Protection with commentaries, Report of the Fifty-Eighth Session, UN Doc. A/61/10, 2006/II(2) ILC Yearbook, Commentary to Article 17, para. 1.

${ }^{47}$ International Law Commission (2006), Draft Articles on Diplomatic Protection, Official Records of the General Assembly, Sixty-first Session, Supplement No. 10, UN Doc. A/61/10, Article 17.
} 
may require the exhaustion of local administrative or judicial remedies as a condition of its consent to arbitration under this Convention. ${ }^{48}$

Article 26 reverses the situation under customary international law: under the Convention, Contracting States waive the requirement of exhaustion of local remedies unless otherwise stated. ${ }^{49}$ The second sentence of Article 26 clarifies that a State may make the exhaustion of local remedies a condition of its consent to arbitration. $^{50}$

A few States have sought to re-instate the exhaustion requirement when acceding to or ratifying the Convention. According to the ICSID website, ${ }^{51}$ Israel, ${ }^{52}$ Costa Rica, ${ }^{53}$ and Guatemala ${ }^{54}$ have made such declarations. ${ }^{55}$

State practice in concluding IIAs shows a diversity of approaches in respect of the exhaustion of local remedies rule. Broadly speaking, IIAs may (1) require exhaustion of local remedies; (2) waive exhaustion of local remedies; or (3) be silent on whether local remedies need to be exhausted prior to commencing arbitration proceedings.

Starting with the first type of treaties, ${ }^{56}$ the requirement to exhaust domestic remedies before resort to international arbitration can in particular be found in early treaties of the 1970s and 1980s. ${ }^{57}$ By contrast, this feature has not appeared in BITs

\footnotetext{
${ }^{48}$ Article 26 (emphasis added).

${ }^{49}$ Schreuer et al. (2009), p. 403.

${ }^{50}$ Schreuer et al. (2009), p. 403.

${ }^{51}$ See ICSID (2019), Contracting States and Measures Taken By Them For The Purpose Of The Convention, Doc. ICSID/8, February 2019, available at https://icsid.worldbank.org/en/Documents/ icsiddocs/ICSID \%208-Contracting\%20States\%20and\%20Measures\%20Taken\%20by $\% 20$ Them $\%$ 20 for $\% 20$ the $\% 20$ Purpose $\% 20$ of $\% 20$ the $\% 20$ Convention.pdf.

${ }^{52}$ On 22 June 1983, Israel notified the Centre that, with reference to Article 26 of the Convention, "Israel requires the exhaustion of local administrative or judicial remedies as a condition under this Convention". This notification was withdrawn by Israel by a communication received by the Centre on 21 March 1991. See ICSID, "Contracting States And Measures Taken By Them For The Purpose Of The Convention", supra note 51, p. 1, footnote 5.

${ }^{53}$ On 27 April 1993, Costa Rica notified the Centre that "[t]here may only be recourse to arbitration pursuant to [the Convention] where all existing administrative or judicial remedies have been exhausted". See ICSID, "Contracting States And Measures Taken By Them For The Purpose Of The Convention", supra note 51, p. 1, footnote 5.

${ }^{54}$ On 16 January 2003, Guatemala notified the Centre that "the Republic of Guatemala will require the exhaustion of local administrative remedies as a condition of its consent to arbitration under the Convention". See ICSID, "Contracting States And Measures Taken By Them For The Purpose Of The Convention", supra note 51, p. 2, footnote 6.

${ }^{55}$ It has been argued that "a general notification of this kind is a statement for information purposes only. [... ] If a State subsequently consents to ICSID arbitration in terms inconsistent with the prior general notification, the consent will prevail over the notification”. See Schreuer et al. (2009), para. 194.

${ }^{56}$ On which see generally Schreuer (2010), pp. 73-74; Schreuer (2005), pp. 1-17; Brauch (2017), pp. 7-12.

${ }^{57}$ See, e.g., Malaysia-Netherlands BIT (1971), Article 12; Netherlands-Singapore BIT (1972), Article XI; Republic of Korea-Netherlands BIT (1974), Article 6; Germany-Israel BIT (1976),
} 
concluded from 2004 to $2012 .^{58}$ One Swiss BIT conditioning consent to arbitration to exhaustion of local remedies "in accordance with international law" is the treaty with Jamaica of 1990. ${ }^{59}$

More recently, the exhaustion rule has re-appeared in treaties of a few States. ${ }^{60}$ Notably, the new Indian Model BIT and a few of the recent treaties entered into by India modelled thereafter, ${ }^{61}$ require "exhaustion" of "all judicial and administrative remedies" for 5 years. ${ }^{62}$ Despite being termed as "exhaustion", the Indian rule is more akin to a prior litigation requirement (on which see infra at Sect. 3.2.3.2) as it does not require the investor to "exhaust" local remedies until the final instance, but calls for litigation of the dispute before the courts for a 5-year period of time.

For those treaties that expressly require exhaustion as a condition to the commencement of arbitration proceedings, the exceptions to the rule under customary international law are likely to apply, i.e. domestic remedies need not be exhausted where they would be "futile" or provide no "reasonable possibility of effective redress". ${ }^{63}$ The treaty may, however, provide for different exceptions. For instance,

Article 10, para. 5; Egypt-Sweden BIT (1978), Article 8; Romania-Sri Lanka BIT (1981), Article 7, para. 2; Denmark-Romania BIT (1994), Article 4, para. 2.

${ }^{58}$ Pohl et al. (2012), p. 14.

${ }^{59}$ Switzerland-Jamaica BIT (1990), Article 9, paras. 4-5.

${ }^{60}$ Albania-Lithuania BIT (2007), Article 8, para. 2. The exhaustion of local remedies rule has been proposed in the context of discussions during the negotiations of the TTIP between the U.S. and the EU. See Porterfield (2015), pp. 1-12. In 2011, the European Parliament adopted a resolution on the EU's international investment policy that stated that "changes must be made to the present [investor-state] dispute settlement regime", including recognizing "the obligation to exhaust local judicial remedies where they are reliable enough to guarantee due process". See European Parliament, Resolution of 6 April 2011 on the Future European International Investment Policy (2010/ 2203(INI)), P7_TA (2011)0141, para. 31.

${ }^{61}$ See India-Belarus BIT (2018), Article 15, para. 2; The India-Taipei Association in Taipei and the Taipei Economic and Cultural Center in India BIT (2018), Article 15, para. 4(b).

${ }^{62}$ India Model BIT (2015), Article 15, para. 2. Commentators have interpreted the clause to mean that "the investor must wait for at least five years even if judicial remedies are exhausted earlier" and suggest that " $[t]$ he underlying rationale for the five-year period might be that the Indian judiciary is heavily backlogged and operates slowly and a five-year period is therefore reasonable in the Indian context". See Hanessian and Duggal (2017), p. 222. The Indian Model BIT also provides a clarification whereby "the investor shall not assert that the obligation to exhaust local remedies does not apply or has been met on the basis that the claim under this Treaty is by a different party or in respect of a different cause of action". See India Model BIT (2015), commentary to Article 15 , para. 1 . As noted by commentators, this language is likely inspired by the desire to avoid certain outcomes linked to a strict application of the "triple identity test" in the context of fork-in-the-road clauses. See Hanessian and Duggal (2017), pp. 216-226, footnote 44. However, the Indian Model BIT contains no fork-in-the-road clause and, in fact, the exhaustion requirement is conceptually antithetical to the fork-in-the-road as the former mandates prior recourse to domestic courts rather than offering a choice of forum. Thus, the rationale of the clause likely is to prevent investors from "resorting to technicalities and to reduce the arbitral discretion". See Ranjan and Anand (2017), p. 50. See also the doubts expressed by Hepburn (2009).

${ }^{63}$ For the exceptions to the exhaustion of local remedies, see the discussion in the commentary of the International Law Commission (2006), Draft Articles on Diplomatic Protection with 
the Indian Model BIT sets forth that domestic remedies need not be exhausted "if the investor or the locally established enterprise can demonstrate that there are no available domestic legal remedies capable of reasonably providing any relief in respect of the same measure or similar factual matters for which a breach of this Treaty is claimed". ${ }^{64}$ This has been read as giving "effect to the 'futility' exception to the exhaustion of local remedies in international law in a limited sense". ${ }^{6}$

Certain IIAs require exhaustion of local remedies for breaches of some but not other substantive standards. For instance, the Australia-Hungary BIT and the Australia-Poland BIT specify that the investor need not exhaust local remedies before submitting claims of expropriation and nationalization to international arbitration. However, for disputes in relation to other substantive standards of protection, local remedies must be exhausted first. ${ }^{66}$

A second group of treaties expressly waive the exhaustion rule. Such waiver is for instance included in BITs concluded by Austria, ${ }^{67}$ the Belgium-Luxembourg Economic Union, ${ }^{68}$ as well as Central and Eastern European States, such as Armenia, Bulgaria, Czech Republic, Croatia, Moldova, Montenegro and Serbia. ${ }^{69}$ By specifying that exhaustion does not apply, States remove any uncertainty especially for

commentaries, Report of the Fifty-Eighth Session, UN Doc. A/61/10, 2006/II(2) ILC Yearbook, Commentary to Article 15. See also Swissborough Diamond Mines (Pty) Limited and others v. Kingdom of Lesotho, PCA Case No. 2013-29, Judgment of the Singapore Court of Appeal, 27 November 2018, paras. 211-222, holding that the only remedies that need to be exhausted are those that are "reasonably available" and that offer a "reasonable possibility of providing effective redress". The Court of Appeal saw no reason for adopting the "less formalistic" approach that prevails in the practice of the European Court of Human Rights, which focuses on whether there is a "reasonable prospect of success". In Swissborough, the applicable treaty, the South African Development Community (SADC) (1992) 32 ILM 116, contained an exhaustion of remedies requirement in the following terms: "Disputes between an investor and a State Party concerning an obligation of the latter in relation to an admitted investment of the former, which have not been amicably settled, and after exhausting local remedies shall, after a period of six (6) months from written notification of a claim, be submitted to international arbitration if either party to the dispute so wishes." See Article 28, para. 1 of Annex 1 to the Protocol on Finance and Investment (2006) of the SADC.

${ }^{64}$ India Model BIT (2015), Article 15, para.1, third sub-paragraph.

${ }^{65}$ Hanessian and Duggal (2017), p. 222.

${ }^{66}$ Australia-Hungary BIT (1991), Article 12; Australia-Poland BIT (1991), Article 13. Similarly, the Poland-United Arab Emirates BIT conditions access to investment arbitration to the exhaustion of local remedies in respect of all claims, except those of expropriation and transfers. See PolandUnited Arab Emirates BIT (1993), Article 9, para. 2.

${ }^{67}$ Austria-Malaysia BIT (1985), Article 9, para. 2; Austria-Tajikistan BIT (2010), Article 15, para. 2.

${ }^{68}$ Belgium-Indonesia BIT (1970), Article 10; Belgium-Luxembourg Economic Union-Montenegro BIT (2010), Article 12, para. 2; Belgium - Luxembourg Economic Union-Cuba BIT (1998), Article 9, para. 2; Belgium-Luxembourg Economic Union-Burundi BIT (1989), Article 8, para. 3. ${ }^{69}$ Croatia-Jordan BIT (1999), Article 10, para. 2(b); Armenia-Netherlands BIT (2005), Article 9, para. 2; Moldovia-Montenegro BIT (2014) (not in force), Article 8, para. 2(b); Bulgaria-Czech Republic BIT (1999), Article 9, para. 4. 
any non-ICSID arbitration options included in the treaty, for which Article 26 of the ICSID Convention would not be applicable. ${ }^{70}$

Finally, the vast majority of treaties are silent on whether domestic remedies need to be exhausted before resort to international arbitration. ${ }^{71}$ Amongst those are the majority of Swiss BITs. ${ }^{72}$

Where the IIA is silent on exhaustion and provides for ICSID arbitration, tribunals have had no difficulty in finding that the customary international law rule on exhaustion does not apply as a consequence of Article 26 of the ICSID Convention. ${ }^{73}$ Within the non-ICSID context, investment tribunals under the ASEAN, ${ }^{74}$ NAFTA Chapter $11,{ }^{75}$ the ECT, ${ }^{76}$ the UNCITRAL Rules ${ }^{77}$ and the SCC Rules, ${ }^{78}$ have held that exhaustion of local remedies is not a condition for bringing an

\footnotetext{
${ }^{70}$ See, e.g., Austria-Slovenia BIT (2001), Article 11, para. 3 providing for various arbitration options, including ICSID, ICC, and UNCITRAL arbitration, and specifying that "[e]ach Contracting Party hereby consents unconditionally to the submission of an investment dispute to international conciliation or arbitration. This consent implies the renunciation of the requirement that the internal administrative or judicial remedies should be exhausted".

${ }^{71}$ Brauch (2017), p. 7.

${ }^{72}$ See Johnson (2015), p. 14.

${ }^{73}$ See Lanco International Inc. v. Argentine Republic, ICSID Case No. ARB/97/6, Preliminary Decision on Jurisdiction, 8 December 1998, paras. 37-39; Generation Ukraine, Inc. v. Ukraine, ICSID Case No. ARB/00/9, Award, 16 September 2003, paras. 13.4-13.5; EDF International S.A., SAUR International S.A. and León Participaciones Argentinas S.A. v. Argentine Republic, ICSID Case No. ARB/03/23, Award, 11 June 2012, paras. 1126-1127; Mr. Franck Charles Arif v. Republic of Moldova, ICSID Case No. ARB/11/23, Award, 8 April 2013, para. 151; Helnan International Hotels A/S v. Egypt, Decision on Annulment, 14 June 2010, paras. 43-47; Amco v. Indonesia, Decision on Annulment, 16 May 1986, 1 ICSID Reports 509, para. 63; IBM v. Ecuador, Decision on Jurisdiction, 22 December 2003, 13 ICSID Reports 105, para. 80; AES v. Argentina, Decision on Jurisdiction, 26 April 2005, 12 ICSID Reports 312, paras. 69-70; Saipem S.p.A. v. The People's Republic of Bangladesh, Decision on Jurisdiction, 21 March 2007, paras. 175; Award, 30 June 2009, paras. 174-184; Emilio Agustin Maffezini v. The Kingdom of Spain, ICSID Case No. ARB/97/7, Decision on Objections to Jurisdiction, 25 January 2000, paras. 22-23.

${ }^{74}$ Yaung Chi Oo Trading Pte. Ltd. v. Government of the Union of Myanmar, ASEAN I.D. Case No. ARB/01/1, Award, 31 March 2003, para. 40.

${ }^{75}$ Waste Management v. The United Mexican States (No. 2), ICSID Case No. ARB(AF)/00/3, Award, 30 April 2004, paras. 116, 133; Waste Management v. The United Mexican States (No. 2), ICSID Case No ARB(AF)/00/3, Decision on Mexico's Preliminary Objection, 26 June 2002, para. 30. See also William Ralph Clayton and others v. Government of Canada, PCA Case No. 2009-04, Judgment of the Federal Court of Canada, 2 May 2018, para. 191 (observing that "the prevailing view appears to be that Article 1121 of Chapter Eleven of NAFTA tacitly waives the requirement that litigants must exhaust local remedies before accessing the Chapter Eleven NAFTA arbitration process").

${ }^{76}$ Nykomb Synergetics Technology Holding $A B$ v. The Republic of Latvia, SCC, Award, 16 December 2003, 11 ICSID Reports 158, sec. 2.4.

${ }^{77}$ CME Czech Republic B.V. v. Czech Republic, UNCITRAL, Final Award, 14 March 2003, paras. 412-413; Mytilineos Holdings SA v. the State Union of Serbia \& Montenegro and the Republic of Serbia, UNCITRAL, Partial Award on Jurisdiction, 8 September 2006, paras. 220-222.

${ }^{78}$ RosinvestCo UK v. Russian Federation, SCC, Award on Jurisdiction, 1 October 2007, para. 153.
} 
investment claim, unless the treaty provides otherwise. This means that in investment arbitration, no matter what arbitration rules govern the proceedings, the customary international rule on exhaustion of local remedies is reversed: the traditional "applicable unless expressly waived" is replaced with "waived unless required". ${ }^{79}$ Several reasons are given in support of this proposition.

First, as seen above, many IIAs include a fork-in-the-road provision or require a prior waiver of all domestic proceedings as a condition to access investor-State arbitration. These provisions have the effect opposite to the exhaustion of local remedies rule. The choice-of-forum requirements can only be enforced if read as an implied waiver of the local remedies rule. ${ }^{80}$

Second, it is said that one objective of entering into an arbitration agreement is to re-allocate jurisdiction over a dispute from the local courts to the arbitral tribunal. Hence, unless expressly agreed otherwise, an arbitration agreement should not be read as requiring prior resolution in the courts. ${ }^{81}$

Finally, investment arbitration was established as a system of direct access for investors to international adjudication alternative to diplomatic protection. ${ }^{82}$ Therefore, some argue that the diplomatic protection principles developed for the invocation of responsibility by a State should not apply to the prosecution of claims by private parties. $^{83}$

Providing greater scope for the exhaustion of local remedies rule in IIAs in investment arbitration has both supporters and detractors. Those who advocate for a more meaningful role of local remedies before resort to international arbitration argue that the exhaustion requirement would strengthen the rule of law in the host States. ${ }^{84}$ Along the same lines, it is said that the fostering of well-functioning judicial institutions in host States "may ultimately help to remedy some of the host-State institutional deficiencies which [investment arbitration was] designed to address", 85 whereas removing investment disputes from the domestic courts discourages local courts from improving the quality of domestic adjudication, ${ }^{86}$ and prevents them "from deciding increasingly important matters". ${ }^{87}$ Furthermore, deferring an investor-State claim until after domestic courts have resolved the dispute may

\footnotetext{
${ }^{79}$ Douglas (2012), pp. 98-99; Sornarajah (2010), p. 221; Crawford (2008), p. 352; Schreuer (2010), pp. 72-73; Muchlinski (2009), p. 345.

${ }^{80}$ Mytilineos Holdings SA v. The State Union of Serbia \& Montenegro and Republic of Serbia, UNCITRAL, Partial Award on Jurisdiction, 8 September 2006, paras. 220-221; Puig (2013), pp. 214-215.

${ }^{81}$ Douglas (2012), p. 98.

${ }^{82}$ See supra at Chap. 2.

${ }^{83}$ Douglas (2004), p. 189; Douglas (2012), pp. 94-96.

${ }^{84}$ Porterfield (2015), p. 5.

${ }^{85}$ UNCTAD (2015), World Investment Report 2015-Reforming International Investment Governance, p. 149 available at https://unctad.org/en/PublicationsLibrary/wir2015_en.pdf.

${ }^{86}$ Ginsburg (2005), pp. 118-119.

${ }^{87}$ Fix-Fierro and López-Ayllón (1997), p. 797.
} 
allow the arbitrator to "benefit from the courts' characterization of the relevant domestic law", 88 in particular, the existence and scope of the property rights.

104 On the other hand, requiring investors to pursue domestic remedies has been criticized for causing delay and increasing costs, ${ }^{89}$ especially since in many States it can take several years and layers of judicial review to reach a final judgment. According to some, insisting on exhaustion of local remedies would also carry disadvantages for the host State, as "[p]ublic proceedings in the domestic courts are likely to exacerbate the dispute and may affect the host State's investment climate". 90 Furthermore, "once the host State's highest court has made a decision, it may be more difficult for the government to accept a compromise or a contrary international judicial decision". 91 The very idea that an investment tribunal has authority to review the decision of the host State's highest court may indeed lie uneasy with a number of States.

\subsubsection{Domestic Litigation Requirements Short of Exhaustion}

105 A minority of BITs 92 "soften" the exhaustion of local remedies rule by subjecting it to a time limit. ${ }^{93}$ In other words, instead of being required to "exhaust" local remedies, the investor must pursue domestic proceedings for a specified period before it may initiate investor-State arbitration. ${ }^{94}$ For the purposes of the domestic litigation requirement, local remedies may include domestic arbitration. ${ }^{95}$

106 A few Swiss BITs with Latin American States include a prior domestic litigation requirement, with some variants from one BIT to the other. The BIT with Argentina requires investors to attempt to settle the dispute before domestic courts for a period of 18 months. If the competent courts do not issue a final judgment ("jugement de dernière instance") within such time period, the investor is entitled to start arbitration proceedings. ${ }^{96}$ The Swiss BIT with Peru also provides a domestic litigation requirement before arbitration proceedings can be started, and specifies that the investor may commence proceedings if "after a period of 18 months there is no decision on the subject matter by the competent national court, or if, existing such a decision, a party to the dispute takes the view that it infringes a provision of [the

\footnotetext{
${ }^{88}$ Porterfield (2015), p. 6.

${ }^{89}$ Tietje and Baetens (2014), p. 95.

${ }^{90}$ Schreuer (2010), p. 73.

${ }^{91}$ Schreuer (2010), p. 73.

${ }^{92}$ Pohl et al. (2012), p. 13. See also Schreuer (2010), p. 74.

${ }^{93}$ See for example, Switzerland-Uruguay BIT (1988), Article 10, para. 2; Convention concerning the Reciprocal Encouragement and Protection of Investments, Belgo-Luxembourg Economic Union-Rwanda (1983), Article 10, paras. 3-4; Jordan-Romania BIT (1992), Article 8, paras. 3-4.

${ }^{94}$ Ortiz et al. (2016), p. 334.

${ }^{95}$ United Arab Emirates-Bangladesh BIT (2011) (not in force), Article 9, para. 3.

${ }^{96}$ Switzerland-Argentina BIT (1991), Article 9.
} 
BIT]". 97 The BITs with Chile and Paraguay are somewhat different in that they offer a choice of forum between domestic courts and investment arbitration, without obliging the investor to pursue the one before the other. However, if the investor has opted for domestic courts, it may commence arbitral proceedings "only if after a period of 18 months there is no decision on the subject matter by the competent national court". 98

Similar variations can be observed in BITs entered into by other countries. ${ }^{99}$ The time period during which the investor is required to pursue domestic remedies varies from 3 months ${ }^{100}$ to several years. ${ }^{101}$ Commonly, the investor is required to pursue domestic proceedings for 18 months. ${ }^{102}$ Some BITs require pursuit of local remedies without a precise time limitation. ${ }^{103}$

Arbitral tribunals have applied prior domestic litigation requirements on a number of occasions. Where the investor had started arbitration proceedings without complying with the domestic litigation requirement under the treaty, tribunals have taken different views as to whether the investor could dispense with this requirement in circumstances where domestic remedies would have been futile or would not have allowed a decision to be reached within the prescribed time limit. ${ }^{104}$

\footnotetext{
${ }^{97}$ Switzerland-Peru BIT (1991), Article 9, para. 3.

${ }^{98}$ Switzerland-Chile BIT (1999), Article 9, para. 3. See also Switzerland-Paraguay BIT (1992), Article 9, para. 3.

${ }^{99}$ See, e.g., Korea-Indonesia BIT (2000), Article 9, para. 2 (entitling the investor to submit the dispute to international arbitration if the "dispute cannot be settled within twelve months between the parties to the dispute through pursuit of local remedies"); U.K.-Argentina BIT (1990), Article 8, para. 2(a) (entitling the investor to submit the dispute to international arbitration if the courts have failed to issue a decision within 18 months or, where the decision has been made, but "the Parties are still in dispute"); U.K.-Uruguay BIT (1991), Article 8, para. 2(a) (entitling the investor to submit the dispute to international arbitration if the courts have failed to issue a final decision within 18 months or where the decision is "manifestly unjust or violates the provisions of this Agreement"); Spain-Uruguay BIT (1992), Article XI, para. 3(a) (providing that the dispute may be submitted to international arbitration "if no decision has been taken on the matter 18 months from the initiation of the judicial proceedings [...], or if such a decision exists but the dispute continues between the parties because one of them considers that the said decision is manifestly unjust or contravenes the provisions of this Agreement or any other norm of international law").

${ }^{100}$ See, e.g., Egypt-U.K. BIT (1975), Article 8, para. 1.

${ }^{101}$ As mentioned above, the Indian Model BIT provides for a 5-year period.

${ }^{102}$ See Pohl et al. (2012), p. 14.

${ }^{103}$ See, e.g., Netherlands-United Arab Emirates BIT (2013), Article 9, para. 3 (providing that "[i]n case of a legal dispute concerning an investment in the territory of the United Arab Emirates, the dispute may only be referred to ICSID if the national, party to the dispute, has first submitted the dispute to the competent court of the United Arab Emirates and the dispute has not been settled to the satisfaction of the national").

${ }^{104}$ Compare, e.g., BG Group Plc. v. The Republic of Argentina, UNCITRAL, Final Award, 24 December 2007, paras. 140-156; Ambiente Ufficio S.p.A. v. Argentine Republic, ICSID Case No. ARB/08/9, Decision on Jurisdiction and Admissibility, 8 February 2013, para. 620; ICS Inspection and Control Services Limited v. The Argentine Republic, PCA Case No. 2010-9, Award on Jurisdiction, 10 February 2012, paras. 265, 269, 273; Giovanni Alemanni and Others v. The Argentine Republic, ICSID Case No. ARB/07/8, Decision on Jurisdiction and Admissibility,
} 
109 The rationale for the prior domestic litigation requirement is similar to the one underlying the exhaustion of local remedies rule, in that it is aimed at giving the host State an opportunity to redress the wrongful act internally before the dispute is elevated internationally. However, prior domestic litigation requirements have also attracted criticism. For instance, in Plama v. Bulgaria, the tribunal described the requirement to undertake a reasonable effort in domestic courts as "nonsensical from a practical point of view". ${ }^{105}$ Critics of domestic litigation requirements have argued that the established timeframe is normally too short to enable a meaningful outcome before the local courts. ${ }^{106}$ Therefore, for the investor, compliance with this requirement is a mere formality that increases the cost and the duration of the dispute settlement. $^{107}$

110 By contrast, others contend that " $[\mathrm{r}]$ estoring a local remedies rule that includes a reasonable, but strict time-frame for those remedies to ensue, [...] while still maintaining a right for an individual to bring a claim directly should those remedies fail, has the potential to balance the rights of investors against the rights of state parties". 108

\subsubsection{Resort to Local Remedies as a Possible Element of Substantive Standards}

111 Resort to local remedies as discussed in the previous two sub-sections is a condition to the jurisdiction of an arbitral tribunal or the admissibility of the claims. It should be distinguished from the situations in which resort to domestic proceedings by a claimant investor has been found to be a condition for the violation of a substantive standard of protection. ${ }^{109}$ This point is addressed briefly here for the sake of completeness.

17 November 2014, paras. 315-316; Philip Morris Brands Sàrl v. Oriental Republic of Uruguay, ICSID Case No. ARB/10/7, Decision on Jurisdiction, 2 July 2013, paras. 144-148; Abaclat and Others (Case formerly known as Giovanna a Beccara and Others) v. Argentine Republic, ICSID Case No. ARB/07/5, Decision on Jurisdiction and Admissibility, 4 August 2011, para. 590; Urbaser S.A. and Consorcio de Aguas Bilbao Bizkaia, Bilbao Biskaia Ur Partzuergoa v. The Argentine Republic, ICSID Case No. ARB/07/26, Decision on Jurisdiction, 19 December 2012, paras. 194 and 202; TSA Spectrum de Argentina S.A. v. Argentine Republic, ICSID Case No. ARB/05/5, Award, 19 December 2008, paras.108-112; İçkale İnşaat Limited Şirketi v. Turkmenistan, ICSID Case No. ARB/10/24, Award, 8 March 2016, para. 260.

${ }^{105}$ Plama Consortium Limited v. Republic of Bulgaria, ICSID Case No. ARB/03/24, Decision on Jurisdiction, 8 February 2005, para. 224.

${ }^{106}$ Schreuer (2005), pp. 4-5.

${ }^{107}$ Schreuer (2010), p. 74.

${ }^{108}$ Bjorklund (2004), p. 286.

${ }^{109}$ See generally Kriebaum (2009), pp. 417-462; Spiermann (2009), pp. 463-489; Demirkol (2018), pp. 75-113. 
There is consensus that exhaustion of local remedies is a required substantive element of a claim for denial of justice. ${ }^{110}$ Beyond denial of justice claims, certain arbitral tribunals have required the claimant investor to resort to local courts to establish violations of other standards of protection. In a number of cases, this requirement has been used to preclude claims for indirect expropriation. ${ }^{111}$ In its analysis on expropriation, the tribunal in Generation Ukraine, for instance, observed that:

[...] it is not enough for an investor to seize upon an act of maladministration, no matter how low the level of the relevant governmental authority; to abandon his investment without any effort at overturning the administrative fault; and thus to claim an international delict on the theory that there had been an uncompensated virtual expropriation. In such instances, an international tribunal may deem that the failure to seek redress from national authorities disqualifies the international claim, not because there is a requirement of exhaustion of local remedies but because the very reality of conduct tantamount to expropriation is doubtful in the absence of a reasonable - not necessarily exhaustive - effort by the investor to obtain correction. $^{112}$

Certain tribunals have also found resort to local remedies relevant for the analysis under the fair and equitable treatment (FET) and full protection and security standards. ${ }^{113}$ In those decisions, the investor was required to show that the host State through its whole process of State function, ${ }^{114}$ rather than isolated acts, had unfairly denied the investor its right to a properly functioning system presenting adequate remedies. ${ }^{115}$

\footnotetext{
${ }^{110}$ Jan de Nul N.V. and Dredging International N.V. v. Republic of Egypt, ICSID Case No. ARB/04/13, Award, 6 November 2008, paras. 255-261; Chevron Corporation and Texaco Petroleum Corporation v. The Republic of Ecuador, UNCITRAL, PCA Case No. 2009-23, Interim Award, 1 December 2008, paras. 235-238. See also Paulsson (2005), pp. 107-112. See also infra at Sect. 3.4.1.

${ }^{111}$ Generation Ukraine v. Ukraine, ICSID Case No ARB/00/9, Award, 16 September 2003, para. 20.33 .

${ }^{112}$ Generation Ukraine v. Ukraine, ICSID Case No ARB/00/9, Award, 16 September 2003, para. 20.30 .

${ }^{113}$ Waste Management v. The United Mexican States (No. 2), ICSID Case No ARB(AF)/00/3, Award, 30 April 2004, para. 116; Loewen Group, Inc and Raymond L Loewen v. United States of America, ICSID Case No ARB(AF)/98/3, Award, 26 June 2003, paras. 154-156.

${ }^{114}$ GAMI Investments, Inc. v. The Government of the United Mexican States, UNCITRAL, Final Award, 15 November 2004, para. 103.

${ }^{115}$ Parkerings-Compagniet AS v. Republic of Lithuania, ICSID Case No ARB/05/8, Award, 11 September 2007, paras. 318-319; Waste Management v. The United Mexican States (No. 2), ICSID Case No ARB(AF)/00/3, Award, 30 April 2004, para. 115; Frontier Petroleum Services v. The Czech Republic, UNCITRAL, Final Award, 12 November 2010, para. 410; Anatolie Stati, Gabriel Stati, Ascom Group S.A. \& Terra Raf Trans Trading v. Republic of Kazakhstan, SCC Arbitration V (116/2010), Award, 19 December 2013, para. 1092; Burlington Resources Inc. v. Republic of Ecuador, ICSID Case No ARB/08/5, Decision on Liability, 14 December 2012, para. 253.
} 
114 Other tribunals have taken a different view and have not required resort to local remedies as a substantive element of alleged breaches other than denial of justice. ${ }^{116}$ Certain commentators have also been critical of the suggestion that violation of substantive international standards has occurred only after redress has been sought through the local courts. ${ }^{117}$ The annulment committee in Helnan v. Egypt set aside the holding from the investment tribunal "which, while disclaiming a requirement of exhaustion of local remedies before ICSID arbitral recourse may be implemented, nevertheless accepts that challenge by [the claimant] of the decision to terminate its [contract] in competent Egyptian administrative courts was required in order to demonstrate the substantive validity of its claims". ${ }^{118}$ In so doing, it explained that:

\begin{abstract}
A single aberrant decision of a low-level official is unlikely to breach the standard unless the investor can demonstrate that it was part of a pattern of state conduct applicable to the case or that the investor took steps within the administration to achieve redress and was rebuffed in a way which compounded, rather than cured, the unfair treatment.
\end{abstract}

But it is an entirely different matter to impose upon an investor, as a condition [for an international wrong] a requirement that the decision of a [governmental organ] must in turn be challenged in the local courts. ${ }^{119}$

115 For the annulment committee, imposing an effort in domestic courts for the perfection of a substantive breach would introduce "by the back door that which the [ICSID] Convention expressly excludes by the front door". ${ }^{120}$

\footnotetext{
${ }^{116}$ See, e.g., Mr. Franck Charles Arif v. Republic of Moldova, ICSID Case No. ARB/11/23, Award, 8 April 2013, paras. 334, 345 (noting that "there is no general requirement to exhaust local remedies for a treaty claim to exist, unless such a claim is for denial of justice. In a claim for denial of justice, the conduct of the whole judicial system is relevant, while in a claim for expropriation, it is the individual action of an organ of the State that is decisive", internal footnote omitted).

${ }^{117}$ See, in particular, Schreuer (2005), pp. 15-16; Schreuer (2010), p. 76.

${ }^{118}$ Helnan International Hotels AS v. Arab Republic of Egypt, Decision of the ad hoc Committee, ICSID Case No ARB/ 05/19, IIC 440, 14 June 2010, para. 73(1).

${ }^{119}$ Helnan International Hotels AS v. Arab Republic of Egypt, Decision of the ad hoc Committee, ICSID Case No ARB/ 05/19, IIC 440, 14 June 2010, paras. 50-51.

${ }^{120}$ Helnan International Hotels AS v. Arab Republic of Egypt, Decision of the ad hoc Committee, ICSID Case No ARB/ 05/19, IIC 440, 14 June 2010, para. 47. In respect of the "effective means" standard and exhaustion, see Chevron Corporation and Texaco Petroleum Company v. The Republic of Ecuador, UNCITRAL (Chevron v. Ecuador I), Partial Award on the Merits, 30 March 2010, para. 326 (holding that while the "strict exhaustion of local remedies is not necessary, [...] a claimant is required to make use of all remedies that are available and might have rectified the wrong complained of. Moreover, a high likelihood of success of these remedies is not required in order to expect a claimant to attempt them."); White Industries Australia Limited v. The Republic of India, UNCITRAL, Final Award, 30 November 2011, paras. 11.4.10-14 (holding that the claimant had not demonstrated that the respondent had failed to provide effective means for it to enforce its rights because the claimant had failed to show that an appeal, which the parties agreed was available as of right to the claimant, would have been "ineffective or futile").
} 


\subsubsection{Conclusive Remarks}

In sum, in seeking to coordinate domestic and international arbitration proceedings, IIAs have essentially followed either a sequential or alternative approach. The sequential approach, implying the prior use or even exhaustion of local remedies, postulates the priority of domestic courts and, according to some, perhaps a belief in the greater effectiveness of national courts in resolving disputes or in the desirability of litigation at the international level after a judicial process has already been pursued or completed at the national level. ${ }^{121}$ However, exhaustion or domestic litigation requirements ultimately leave the door open to investment arbitration. By contrast, the alternative approach starts from the idea that domestic courts and investment arbitration are equivalent (at least in theory), leaves the choice of forum to the claimant-investor once the dispute has arisen, and then provides rules to avoid overlaps between the two proceedings.

In spite of these attempts, the lex lata is not always able to capture the complexity of the interactions deriving from the fact that, although identical in substance as well as in economic terms, the dispute before the two fora is often not the "same" in strict legal terms (the parties sometimes and most often the legal basis of the claims being different). Hence, de lege ferenda and to the extent that States consider it their policy to discourage multiple proceedings about the same measure, fork-in-the-road and waiver clauses should be phrased more broadly and cater for these situations.

\subsection{Domestic Courts in Support and Control of Investor-State Arbitral Tribunals}

Once an investor has started or intends to start arbitration proceedings, courts can have important supervisory functions over the arbitration process or, otherwise said, they can support or control the arbitration in multiple ways. In this context, a significant distinction exists between an investment arbitration conducted under the ICSID Convention (herein below, "ICSID arbitration" for brevity) and one conducted under any other rules, such as the ICSID Additional Facility (AF), UNCITRAL, ICC, SCC Rules, and others ("non-ICSID arbitration"). In the case of ICSID arbitration, the Washington Convention establishes a "delocalized" procedural framework, ${ }^{122}$ governed exclusively by public international law. In ICSID arbitration, the arbitration law of the seat (or lex arbitri) plays no role and national courts have no jurisdiction in aid or control of the arbitration. In other words, the "self-contained" process which States designed under the ICSID Convention is

\footnotetext{
${ }^{121}$ Shany (2007), p. 28.

${ }^{122}$ See generally Delaume (1983), pp. 784-803; Bernardini (2010), pp. 159-188, para. 7.
} 
geared towards making arbitration independent of domestic courts. ${ }^{123}$ This entails that any aspects of the arbitral process (appointment of arbitrators, challenges, annulment, revision, etc.) is addressed within the machinery of the Centre established by the ICSID Convention.

119 By contrast, non-ICSID investor-State arbitrations do not benefit from this "delocalization" and, like international commercial arbitrations, are subject to a national lex arbitri. For non-ICSID arbitrations, the role of courts in support and control of investment arbitrations is thus potentially much more significant. Non-ICSID arbitrations seated in Switzerland are governed by Chapter 12 of the Swiss Federal Private International Law Act (PILA) ${ }^{124}$ and subject to the jurisdiction of the courts of the seat as juge d'appui and of the Swiss Federal Tribunal for annulment actions. They are thus submitted to the same regime as international commercial arbitrations with a seat in Switzerland.

120 As mentioned at the outset of this study (see supra in Chap. 1), Switzerland has been traditionally one of the most chosen seats for international arbitration in general, including non-ICSID investment arbitrations, due to, inter alia, the country's reputation for neutrality and stability as well as the legislation's and the judiciary's pro-arbitration approach. In the last few years, there has been an increase in Swiss-seated investment treaty arbitrations, a trend which may well continue especially for intra-EU disputes as a result of the uncertainties arising from the judgment by the CJEU in Achmea. ${ }^{125}$ An increase of Swiss-seated arbitrations means, in turn, a potentially greater involvement of the Swiss Federal Tribunal with investment matters, as can already be observed from the growing number of set aside applications of investment awards brought before the Swiss Federal Tribunal (see infra Table 3.1, at Sect. 3.3.4, Annulment proceedings of investment awards).

121 The following sections provide an overview of the situations in which domestic courts may rule on investment arbitration matters.

\footnotetext{
${ }^{123}$ Schreuer et al. (2009), p. 351.

${ }^{124}$ References in this report to Chapter 12 of the PILA are to the provisions in the statute that are currently in force at the time of writing. It should be noted that Chapter 12 PILA is currently undergoing a revision. The legislative process to that end is nearing completion. On 24 October 2018, the Swiss Federal Council published its Draft Bill on the reform of Chapter 12 PILA, accompanied by an Explanatory Report addressed to the Swiss Parliament. See Message concernant la modification de la loi fédérale sur le droit international privé (Chapitre 12 Arbitrage international) and Loi fédérale sur le droit international privé (LDIP) (Projet), both published in the Swiss Federal Gazette No. 47 of 27 November 2018, available at https://www.admin.ch/opc/fr/ federal-gazette/2018/index_47.html (also available in German and Italian). The Draft Bill is due to be reviewed and debated by both Swiss parliamentary chambers in 2019. See Swiss Parliament, Loi sur le droit international privé, Chapitre 12: Arbitrage international, available at https://www. parlament.ch/fr/ratsbetrieb/suche-curia-vista/geschaeft?AffairId=20180076. At the time of writing, it is expected that the revised text of Chapter 12 PILA will be enacted in 2020 and will enter into force in 2021.

${ }^{125}$ See CJEU C-284/16, Slovak Republic v. Achmea BV, 6 March 2018.
} 


\subsubsection{Enforcement of Arbitration Agreement}

In a first type of situation, a party may submit a dispute to a domestic court notwithstanding the existence of an agreement between the parties to submit such dispute to investment arbitration. It is most likely that the defendant in the domestic court proceedings will then raise a defense of lack of jurisdiction on the basis of the arbitration agreement, or exceptio arbitri.

In non-ICSID investment arbitrations, domestic courts of State Parties to the New York Convention (NYC) ${ }^{126}$ have a duty to decline jurisdiction, in accordance with Article II, para. 3, of the Convention, which provides that "the court of a Contracting State, when seized of an action in a matter in respect of which the parties have made a [valid arbitration] agreement, shall, at the request of one of the parties, refer the parties to arbitration unless it finds that the said agreement is null and void, inoperative or incapable of being performed". Article 7 of the PILA provides for a similar rule. $^{127}$

An analogous result is reached in ICSID arbitrations by operation of the exclusivity rule contained in Article 26 of the ICSID Convention. As explained by George Delaume:

[...] If a court in a Contracting State [to the ICSID Convention] becomes aware of the fact that a claim before it may call for adjudication under ICSID, the court should refer the parties to ICSID to seek a ruling on the subject. Until such a ruling is made, if the possibility exists that the claim may fall within the jurisdiction of ICSID, the court must stay the proceedings pending proper determination of the issue by ICSID. ${ }^{128}$

Courts of a number of countries, including Swiss courts, have recognized these rules when seized of disputes for which an investment arbitration clause was operative. ${ }^{129}$ In MINE v. Guinea, for instance, in the context of attachment proceedings of an arbitral award rendered under the aegis of the American Arbitration Association, notwithstanding the parties' agreement to refer their disputes to ICSID arbitration, the Swiss Federal Tribunal acknowledged the exclusivity of ICSID

\footnotetext{
${ }^{126}$ New York Convention of 10 June 1958 on the Recognition and Enforcement of Foreign Arbitral Awards (NYC).

${ }^{127}$ Article 7 of the PILA provides as follows: "[i]f the parties have entered into an arbitration agreement [and one of the parties brings an action before a Swiss court], the court must decline jurisdiction unless: (a) the respondent has proceeded on the merits without raising an objection, (b) the arbitration agreement is null and void, ineffective, or incapable of being performed, (c) the arbitral tribunal cannot be constituted for reasons manifestly attributable to the respondent in the arbitration".

${ }^{128}$ Delaume (1984), p. 68 (footnote omitted), quoted in Schreuer et al. (2009), p. 386.

${ }^{129}$ These cases have mainly concerned instances where the basis of consent to ICSID jurisdiction was an arbitration clause in an investment contract. Similar results would, however, be reached, mutatis mutandis, where consent is perfected through the investor's acceptance of an arbitration offer contained in an IIA.
} 
proceedings by virtue of Article 26 of the ICSID Convention. ${ }^{130}$ In the subsequent proceedings before the Geneva Court of First Instance, the Court also affirmed the exclusive character of consent to ICSID arbitration in the following terms:

According to the [contract], the parties agreed to submit their differences to ICSID. Proceedings initiated by MINE on 7 May 1984 are now pending before the ICSID Arbitral Tribunal. According to Article 26 of the [ICSID Convention], the consent of the parties to arbitration under the Convention is, unless otherwise agreed, considered as implying a waiver of all other remedies. As Switzerland has ratified the Convention it is now part of Swiss law. It should be recognized that, in referring to this Court, the applicant is not acting in conformity with Article 26 of the Convention. [...] Since the request which MINE has filed with the Court is contrary to the exclusive nature of ICSID arbitration as provided in Article 26 of the Washington Convention of 18 March 1965, MINE cannot appear before this Court. ${ }^{131}$

126 The subsequent decision by the Supervisory Authority of the Office des Poursuites for the Enforcement of Debts and Bankruptcy of Geneva also relied on Article 26 of the ICSID Convention when rejecting MINE's attempt to maintain the attachments. $^{132}$

127 In other cases, domestic courts were asked to enjoin parties from instituting or continuing ICSID proceedings notwithstanding a prima facie valid consent to ICSID arbitration. In those instances, where a prima facie valid consent to arbitration exists, it would not be permissible for a court to enjoin a party from pursuing the investment arbitration. In Attorney-General v. Mobil Oil NZ Ltd, for instance, the New Zealand Government commenced proceedings in its courts to seek to enjoin the investor from continuing to refer the dispute to ICSID in accordance with the agreement entered

\footnotetext{
${ }^{130}$ See Swiss Federal Tribunal, Maritime International Nominees Establishment (MINE) v. Republic of Guinea, decision of 4 December 1985, ASA Bulletin (1987) 26 (excerpts) (where the Swiss Federal Tribunal noted that "[a]ccording to [Article 26] of the Washington Convention, the consent of the parties to arbitration within the framework of this Convention is, unless otherwise agreed, considered to imply waiver of the exercise of any other remedy. It follows that the respondent company, to the extent that it is validly bound by the ICSID arbitration clause, must respect the exclusive nature of that procedure. The respondent company cannot therefore have recourse against the appellant to any other measure of asserting pressure or other remedy [...]").

${ }^{131}$ Geneva Court of First Instance, MINE v. Republic of Guinea, decision of 13 March 1986, ASA Bulletin (1987), 28 (excerpts).

${ }^{132}$ See Autorité de surveillance des offices de poursuite pour dettes et de faillite, MINE v. Republic of Guinea, decision of 7 October 1986, ASA Bulletin (1987), 33 (excerpts); 4 ICSID Report 45 (1997) (excerpts); English translation of French original in 26 ILM (1987) 382. The Belgian courts in the same dispute similarly noted ICSID's exclusive competence and found that the proceedings to obtain a seizure fell within the definition of "remedy" in Article 26 and were hence inadmissible. See Guinea v. MINE, Belgium, Court of First Instance, Antwerp, 27 September 1985, 4 ICSID Reports 32. See also Brief for the United States of America as Intervenor and Suggestion of Intent, 20 ILM 1436 (1981) in the same dispute before the U.S. courts (in which the United States stated that " $[\mathrm{t}] \mathrm{o}$ prevent United States courts from improperly asserting jurisdiction over ICSID cases, and to accord the necessary deference to ICSID's jurisdictional autonomy, the United States submits that a rule of abstention should be followed in U.S. courts" and that "a case brought in a United States court which arguably falls within ICSID's exclusive jurisdiction should be stayed to permit ICSID to resolve whether it has jurisdiction").
} 
into by the parties. The High Court of New Zealand found that under the contract, either party was entitled to refer the dispute to ICSID and stayed the domestic proceedings until the ICSID tribunal had determined its jurisdiction. ${ }^{133}$ This being so, domestic courts do not always pay deference to Article 26 of the ICSID Convention in this fashion. For instance, in the dispute between SGS and Pakistan, Pakistan commenced domestic arbitration proceedings in Pakistan pursuant to the dispute settlement clause contained in the contract, while SGS subsequently started ICSID proceedings under the Swiss-Pakistan BIT. ${ }^{134}$ Each party then applied to the Pakistani courts for injunctions to restrain the other party from pursuing their chosen arbitration option. ${ }^{135}$ The Supreme Court of Pakistan ultimately granted Pakistan's request to proceed with the contract arbitration and "restrain[ed] [SGS] from pursuing or participating in the ICSID arbitration". ${ }^{136}$

It should also be noted that in several instances where a domestic court has been seized by a party in an attempt to circumvent investment arbitration proceedings, investment tribunals have been requested to issue provisional measures to restrain that party from initiating or continuing proceedings in another forum, be they arbitration, civil, criminal, bankruptcy, or enforcement proceedings. ${ }^{137}$

There is abundant practice of arbitral tribunals granting interim relief to enjoin parallel domestic litigation. A study of all the known provisional measures decisions issued by ICSID tribunals between 1972 and 2009 shows that over 50\% of those decisions concerned a request to enjoin parties from pursuing parallel domestic proceedings. ${ }^{138}$ Provisional measures seeking to restrain a party from commencing or continuing parallel domestic litigation are usually requested by the investor, although in certain cases they have also been sought by the State. ${ }^{139}$ In essence, investment tribunals have found justification for the issuance of interim relief (sometimes in the form of an "anti-suit injunction"), ${ }^{140}$ in the exclusive remedy rule of Article 26 of the ICSID Convention (where such provision was applicable),

\footnotetext{
${ }^{133}$ See Attorney-General v. Mobil Oil NZ Ltd, New Zealand, High Court, Wellington, 1 July 1987, 2 ICSID Review-Foreign Investment Law Journal 497 (1987).

${ }^{134}$ SGS Société Générale de Surveillance S.A. v. Pakistan, ICSID Case No. ARB/01/13, Decision on Jurisdiction, 6 August 2003, paras. 1-2.

${ }^{135}$ SGS Société Générale de Surveillance S.A. v. Pakistan, ICSID Case No. ARB/01/13, Decision on Jurisdiction, 6 August 2003, paras. 35-38.

${ }^{136}$ SGS Société Générale de Surveillance S.A. v. Pakistan, ICSID Case No. ARB/01/13, Decision on Jurisdiction, 6 August 2003, para. 39.

${ }^{137}$ See generally, Brower and Goodman (1991), pp. 431-461; Kalderimis (2016), pp. 549-575; Gil (2009), pp. 353-602; Kaufmann-Kohler et al. (2018), pp. 647-649.

${ }^{138}$ Gil (2009), p. 540.

${ }^{139}$ See Atlantic Triton Company Limited v. People's Revolutionary Republic of Guinea, ICSID Case No. ARB/84/1/, 21 April 1986 and MINE v. Republic of Guinea, ICSID Case No. ARB/84/4, 6 January 1988. As Gil notes, both these cases related to attachments by domestic courts. See Gil (2009), p. 544.

${ }^{140}$ I.e., an order that restrains, directly or indirectly, temporarily or permanently, the continuation of proceedings before another tribunal or court.
} 
and/or in the need to protect the tribunal's jurisdiction, the integrity of the arbitration proceedings, or in the prohibition of aggravating the dispute. ${ }^{141}$

130 To limit the discussion to two examples in relation to the court proceedings mentioned above, in the dispute between MINE and Guinea, ${ }^{142}$ the ICSID tribunal recommended that MINE terminate any proceedings in connection with the dispute and any attachment and provisional measures pending in national courts. ${ }^{143}$ Both the Geneva Court of First Instance and the Geneva Bankruptcy Supervision Authority referred to the provisional measures issued by the ICSID tribunal in their decisions giving precedence to ICSID arbitration based on Article 26 of the ICSID Convention. ${ }^{144}$

131 Regarding concurrent arbitration proceedings, in SGS v. Pakistan, SGS requested the ICSID arbitral tribunal to recommend "that the Islamabad-based

\footnotetext{
${ }^{141}$ In arbitrations under the UNCITRAL 2010 Rules, Article 26, para. 2(b) allows interim measures to prevent a party from taking action that is likely to cause "prejudice to the arbitral process itself". Certain IIAs, such as NAFTA and the EU-Canada FTA, also specifically mention the purpose of protecting the tribunal's jurisdiction amongst the reasons for interim relief. Thus, according to Article 1134 of the NAFTA, "[a] Tribunal may order an interim measure of protection to preserve the rights of a disputing party, or to ensure that the Tribunal's jurisdiction is made fully effective". See also Agreement between the United States of America, the United Mexican States, and Canada (USMCA), 30 November 2018, Article 14.D.7, para. 9. The U.S. Model BIT (2012), as well as numerous recent treaties concluded by the United States, contain wording similar to the NAFTA provision just quoted. Similar language is also present in Article 8.34 of the EU-Canada Comprehensive Economic and Trade Agreement (CETA). Likewise, Article 3.7, para. 4 of the EU-Singapore Investment Protection Agreement (2018) allows investors to request interim measures before arbitration tribunals in order to preserve their rights and interests as claimants, while vesting the same prerogative in domestic courts if interim relief is sought before the constitution of the tribunal. See also EU-Vietnam Investment Protection Agreement (2019), Article 3.47.

${ }^{142}$ See supra para. 125 . The MINE tribunal was the first ICSID tribunal to grant provisional measures to enjoin parallel domestic proceedings. See Gil (2009), pp. 553-554.

${ }^{143}$ MINE v. Republic of Guinea, ICSID Case No. ARB/84/4, Decision on Provisional Measures, 4 December 1985. For an analysis of Atlantic Triton and MINE, see Friedland (1986), pp. 335-357; see also Parra (1993), pp. 37-44.

${ }^{144}$ See Geneva Court of First Instance, MINE v. Republic of Guinea, decision of 13 March 1986, ASA Bulletin (1987), 28 (excerpts) ("The ICSID Arbitral Tribunal itself held that the litigation instituted by MINE in the national courts constitutes a violation of its request for ICSID arbitration and constitutes an 'other remedy' as defined in Article 26 of the Convention. In its decision on provisional measures dated 4 December 1985, the ICSID Arbitral Tribunal recommended to MINE that it withdraw and permanently discontinue all pending litigation in the national courts, as well as dissolve all other provisional measures"); Autorité de surveillance des offices de poursuite pour dettes et de faillite, MINE v. Republic of Guinea, decision of 7 October 1986, ASA Bulletin (1987), 33 (excerpts); 4 ICSID Report 45 (1997) (excerpts) (“[...] the [ICSID] Arbitral Tribunal [...] recommended to MINE, in its decision on provisional measures of 4 December 1985, that it should withdraw and permanently discontinue all pending litigation before national courts as well as withdraw all other provisional measures. The competent Authority observes that, in resorting to ICSID arbitration proceedings, MINE waived the ability to request provisional measures against the Republic of Guinea in Switzerland. Therefore MINE is committing a manifest abuse of the law in invoking these ICSID proceedings to attempt to obtain the maintenance of an attachment, which is the typical provisional measure").
} 
arbitration pending between SGS and Pakistan be stayed". ${ }^{145}$ Finding that SGS had "a prima facie right to seek access to international adjudication under the ICSID Convention", ${ }^{146}$ the tribunal considered it its "duty to protect this right". ${ }^{147}$ It thus recommended that Pakistan inform all the relevant domestic courts of the current standing of the ICSID arbitration and ensure that no action be taken to hold SGS in contempt of court. In parallel, the tribunal also recommended that local arbitration proceedings be stayed until the tribunal decided on its jurisdiction. ${ }^{148}$ By contrast, it rejected a broader request for an injunction refraining Pakistan from commencing or participating in proceedings relating in any manner to the ICSID arbitration. This latter request was deemed to restrain the ordinary exercise of Pakistan's normal process of justice. ${ }^{149}$

These types of incidents of court- and tribunal-issued injunctions display a tangible tension between international tribunals and domestic courts where both adjudicative institutions purport to assert jurisdiction over matters relating to the dispute. If these matters are the merits of the investment dispute and there is a valid (or prima facie valid) investor-State arbitration agreement, then the jurisdiction of the investment tribunal should prevail. This is not necessarily correct when the matters at issue are merely ancillary to the dispute, such as provisional or interim relief. Article 26 of the ICSID Convention will, in principle, bar the jurisdiction of domestic courts also in this context. ${ }^{150}$ The position in non-ICSID arbitrations will depend on any specific IIA provision, the lex arbitri, or the applicable arbitration rules. Be that as it may, the issuance of an antisuit injunction always requires careful balancing of a number of principles at play, including the principle of competencecompetence of courts and tribunals, which is a general principle of procedure, ${ }^{151}$ and

${ }^{145} \mathrm{~S} G S$ Société Générale de Surveillance S.A. v. Islamic Republic of Pakistan, ICSID Case No. ARB/01/13, Procedural Order No 2, 16 October 2002, 18 ICSID Review-Foreign Investment Law Journal (2003), p. 293.

${ }^{146}$ SGS Société Générale de Surveillance S.A. v. Islamic Republic of Pakistan, ICSID Case No. ARB/01/13, Procedural Order No 2, 16 October 2002, 18 ICSID Review—Foreign Investment Law Journal (2003), p. 299.

${ }^{147}$ SGS Société Générale de Surveillance S.A. v. Islamic Republic of Pakistan, ICSID Case No. ARB/01/13, Procedural Order No 2, 16 October 2002, 18 ICSID Review-Foreign Investment Law Journal (2003), p. 300.

${ }^{148}$ SGS Société Générale de Surveillance S.A. v. Islamic Republic of Pakistan, ICSID Case No. ARB/01/13, Procedural Order No 2, 16 October 2002, 18 ICSID Review—Foreign Investment Law Journal (2003), p. 304.

${ }^{149}$ See SGS Société Générale de Surveillance S.A. v. Islamic Republic of Pakistan, ICSID Case No. ARB/01/13, Procedural Order No 2, 16 October 2002, 18 ICSID Review-Foreign Investment Law Journal (2003), p. 301 (where the tribunal held that "[w]e cannot enjoin a State from conducting the normal processes of criminal, administrative and civil justice within its own territory. We cannot, therefore, purport to restrain the ordinary exercise of these processes").

${ }^{150}$ Subject to a different agreement between the parties in their instrument recording their consent to arbitration. See ICSID Arbitration Rules, Rule 39, para. 6. See also infra at Sect. 3.3.3.

${ }^{151}$ Nottebohm Case (Liechtenstein v. Guatemala), Preliminary Objections, Judgement of November 18, 1953, I.C.J. Reports 1953, pp. 119-20. 
the States' sovereignty to exercise their powers to conduct national proceedings within their territory. ${ }^{152}$ The latter is particularly pertinent when the local proceedings which are sought to be enjoined are criminal proceedings. ${ }^{153}$

\subsubsection{Assistance with the Arbitral Process (Appointment of Arbitrators, Decision on Challenges, etc.)}

133 Difficulties may arise in the course of the arbitration proceedings if, for instance, a party fails to perform certain steps, such as appointing its arbitrator. Due to its insulated nature, ICSID arbitration does not require assistance from the courts. Rather, any difficulties in the course of the proceedings are resolved by the Centre, which may be called upon to assist with the appointment of arbitrators, rule on proposals for disqualification, and the like.

134 In non-ICSID arbitrations which are subject to a national lex arbitri, courts have, at least in theory, a greater role to play in these matters. Most national arbitration laws provide that the parties or the arbitral tribunal may request the assistance of the courts in the event of difficulties. Under Swiss law as well as other legal systems (notably, France), ${ }^{154}$ the court called upon to act in this capacity is often referred to as juge d'appui, emphasizing that the court acts in support of the arbitration. ${ }^{155}$ Assistance may be required in connection with the constitution of the arbitral tribunal if a party refuses to appoint an arbitrator or to participate in the appointment of a sole arbitrator, if the two parties cannot agree on a sole arbitrator or if the two party-appointed arbitrators cannot agree on the tribunal's president. Support from the judge at the seat may also be required in respect of resolving a challenge to arbitrators and other types of actions. Swiss law provides for such assistance in Articles 179, para. 2, and 180, para. 3, PILA.

135 In practice, however, courts rarely have to step in to assist disputing parties with the matters just referred to. Most non-ICSID arbitrations are conducted pursuant to institutional (e.g., ICC or SCC) or non-institutional (e.g., UNCITRAL) arbitration rules that entrust either an arbitral institution or another appointing authority with support functions. By submitting to arbitration under those rules, parties agree to resort to that arbitral institution or appointing authority for support. As a result, the rules contained in the arbitration laws of most countries providing for the court's role as juge d'appui, which apply only in the absence of party agreement, are not triggered. To give an example, in an investment treaty arbitration conducted under the UNCITRAL Rules, difficulties arising with the constitution of the tribunal and challenges to arbitrators will be resolved by an appointing authority chosen by the

\footnotetext{
${ }^{152}$ For further discussion, see Kalderimis (2016), pp. 549-575.

${ }^{153}$ See Kaufmann-Kohler et al. (2018), pp. 654-655.

${ }^{154}$ See Article 1505 of the French Code of Civil Procedure.

${ }^{155}$ See Kaufmann-Kohler and Rigozzi (2015), p. 57.
} 
parties or, in the absence of such a choice, designated by the PCA. ${ }^{156}$ The PCA's practice in investment cases appears to be to designate individuals as appointing authorities. ${ }^{157}$ Although rare in practice, the appointing authority chosen by the parties or designated by the designating authority could in theory also be a domestic court. $^{158}$

In addition to matters concerning the appointment and replacement of arbitrators, the assistance of the courts may be requested whenever a compulsory order is required in connection with the conduct of the proceedings (Article 185 PILA), in particular with respect to the taking of evidence (Article 184, para. 2 PILA), for instance to summon a witness who refuses to appear before the arbitral tribunal or to compel a third party to produce documents (section 1782 of Title 28 of the United States Code).

\subsubsection{Provisional Measures Issued by Courts}

There may be instances where a party wishes to seek interim relief from domestic courts, for example if the tribunal is not yet constituted or if it is constituted but has no jurisdiction to grant the requested measures, or when a measure is directed at a third party, or a court-ordered measure is deemed more efficient. ${ }^{159}$

\footnotetext{
${ }^{156}$ See, e.g. UNCITRAL Rules (2010), Article 6, para. 2 (providing that "[i]f all parties have not agreed on the choice of an appointing authority within 30 days after a proposal made in accordance with paragraph 1 has been received by all other parties, any party may request the Secretary-General of the PCA to designate the appointing authority"). On the constitution of the tribunal see Article 8 , para. 1 (providing that if the parties have agreed that a sole arbitrator is to be appointed but are unable to reach agreement on that sole arbitrator within 30 days, "a sole arbitrator shall, at the request of a party, be appointed by the appointing authority") and Article 9, paras. 1 and 2 (providing that where three arbitrators are to be appointed, "[i]f within 30 days after the receipt of a party's notification of the appointment of an arbitrator the other party has not notified the first party of the arbitrator it has appointed, the first party may request the appointing authority to appoint the second arbitrator" and "[i]f within 30 days after the appointment of the second arbitrator the two arbitrators have not agreed on the choice of the presiding arbitrator, the presiding arbitrator shall be appointed by the appointing authority [...]"). On the challenge to an arbitrator, see Article 13, para 4 (providing that "[i]f, within 15 days from the date of the notice of challenge, all parties do not agree to the challenge or the challenged arbitrator does not withdraw, the party making the challenge may elect to pursue it. In that case, within 30 days from the date of the notice of challenge, it shall seek a decision on the challenge by the appointing authority").

${ }^{157}$ See Gaukrodger (2018), paras. 205-222, available at http://www.oecd.org/investment/invest ment-policy/ISDS-Appointing-Authorities-Arbitration-March-2018.pdf.

${ }^{158}$ For instance, the PCA, acting as the designating authority for the Iran-U.S. Claims Tribunal which operates under a revised version of the UNCITRAL Rules, has designated the president of the Supreme Court of the Netherlands as appointing authority for the Iran-U.S. Claims Tribunals. See Gaukrodger (2018), para. 210 (with further references), available at http://www.oecd.org/ investment/investment-policy/ISDS-Appointing-Authorities-Arbitration-March-2018.pdf.

${ }^{159}$ See generally Kaufmann-Kohler et al. (2018), pp. 677-678.
} 
In the ICSID context, as already mentioned, Article 26 of the Convention provides that, unless otherwise stated, consent to ICSID arbitration is given to the exclusion of any other remedy. ${ }^{160}$ It was initially debated whether this exclusion applied to interim relief which a party would request before domestic courts. ${ }^{161}$

139 In 1984, Arbitration Rule 39, para. 6 (formerly Rule 39, para. 5) was introduced to clarify that, except when otherwise stipulated, the parties waive their right to seek interim measures of protection in domestic courts, whether before or after the institution of the ICSID proceedings. For this rule not to apply, the parties must have stipulated so in the agreement recording their consent, namely in the arbitration clause, be it in a contract, ${ }^{162}$ national legislation, or a treaty. An illustration of such a stipulation in an IIA can be found in NAFTA Article 1121. ${ }^{163}$ Arbitration Rule 39 , para. 6 is a further illustration of the insulated nature of ICSID proceedings.

140 By contrast to the Arbitration Rules for arbitrations under the ICSID Convention, Article 46 of the ICSID AF Arbitration Rules expressly authorizes the parties to request assistance from local courts to obtain interim relief. Article 46, para. 4 specifies that, by doing so, the parties are not infringing upon the agreement to arbitrate or affecting the powers of the arbitral tribunal. This feature is explained by the absence of an insulated mechanism in the AF Rules and the fact that AF arbitration is generally subject to a national legal order. ${ }^{164}$ Similarly, in the UNCITRAL context, Article 26, para. 3 of the 1976 Arbitration Rules and Article 26, para. 9 of the 2010 Arbitration Rules allow the parties to seek interim relief from domestic courts. Such action is not seen as a breach or waiver of the agreement to arbitrate.

\footnotetext{
${ }^{160}$ See supra paras. 68,124 et seq.

${ }^{161}$ See Parra (1993), pp. 37-38. Some authors suggested that since an ICSID tribunal can only recommend measures, "the Contracting States did not intend to deprive national courts of the power to prescribe provisional measures". See Collins (1992-III), p. 99.

${ }^{162}$ For instance, the parties could insert into their contract the language of ICSID Model Clause 14, available on the ICSID website, which reads as follows: "Without prejudice to the power of the Arbitral Tribunal to recommend provisional measures, either party hereto may request any judicial or other authority to order any provisional or conservatory measure, including attachment, prior to the institution of the arbitration proceeding, or during the proceeding, for the preservation of its rights and interests". See ICSID Model Clauses, available at http://icsidfiles.worldbank.org/icsid/ icsid/staticfiles/model-clauses-en/14.htm.

${ }^{163}$ However, Article 1121 NAFTA (entitled "Conditions Precedent to Submission of a Claim to Arbitration") complements the applicable arbitration rules and limits the nature of the relief sought and the courts from which such relief may be requested. It states that, by consenting to arbitration under Chapter 11, a party (an investor on its own behalf or on behalf of an enterprise) waives its right to resort to domestic courts "except for proceedings for injunctive, declaratory or other extraordinary relief, not involving the payment of damages, before an administrative tribunal or court under the law of the disputing Party".

${ }^{164}$ Parra (1993), p. 40.
} 


\subsubsection{Annulment Proceedings}

Annulment of awards is another area where there is a remarkable difference between ICSID and non-ICSID arbitration. The ICSID Convention offers its own selfcontained system of review of awards, whereby an ad hoc annulment committee reviews awards based on the grounds for annulment listed in Article 52 of the Convention. Thus, any role for national courts in the annulment of ICSID awards is excluded by the Convention.

Awards rendered in non-ICSID arbitrations, by contrast, are subject to the postaward remedies provided by the law of the seat of the arbitration. ${ }^{165}$ Annulment (or set aside or vacatur) is thus the area which perhaps showcases the most important role for domestic courts in respect of non-ICSID arbitrations. National arbitration laws follow a variety of approaches in setting out the grounds upon which an arbitral award can be set aside, the standard of review to be followed by the domestic courts, the number of layers of review (one, two, and in certain States even three instances) and the courts competent to review annulment applications. Generally speaking, a comparative analysis of the most important arbitration laws of the world shows that challenges against arbitral awards may only be brought on the basis of a few, narrowly defined grounds of an essentially procedural nature, which include lack of jurisdiction, irregular constitution of the tribunal and lack of impartiality and independence of its members, breach of due process, and public policy (which is the only ground allowing a limited review of the merits). In other words, annulment is concerned with the integrity of the proceedings and not the correctness of the decision.

In Switzerland, non-ICSID arbitral awards can be set aside based on one of the grounds listed in Article 190 of the PILA by the Swiss Federal Tribunal. ${ }^{166}$ As a result of the growing importance of Switzerland (in particular, Geneva) as a seat of investment arbitrations, the Swiss Federal Tribunal has been seized with a good number of applications for the set aside of investment awards in the last 20 years. In line with the approach followed in other jurisdictions, the Swiss Federal Tribunal admits challenges against non-ICSID awards rendered in disputes arising under investment treaties, when the conditions set out in Chapter 12 of the PILA are fulfilled and according to Article 77 of the Federal Tribunal Act. ${ }^{167}$

Swiss law allows parties to waive their right to seek the annulment of the award, provided the parties lack any territorial connection with Switzerland and the expression of their intent to exclude annulment proceedings meets certain form requirements. ${ }^{168}$ According to the Swiss Federal Tribunal, the parties must clearly and

\footnotetext{
${ }^{165}$ See generally Hober and Eliasson (2018), pp. 759-796.

${ }^{166}$ On challenges of investment arbitration awards before the Swiss Federal Tribunal, see generally Scherer et al. (2009), pp. 256-279; Radjai and Stirnimann (2013), pp. 1096-1099.

${ }^{167}$ Loi sur le Tribunal fédéral, RS 173.110.

${ }^{168}$ See Article 192, para. 1 PILA (providing that "[i]f none of them has its domicile, habitual residence, or a business establishment in Switzerland, the parties may, by an express statement in
} 
unambiguously state their intent to waive the right to challenge the award in accordance with Article 190, para. 2 PILA. ${ }^{169}$ In a decision dealing with the award on jurisdiction in Saluka v. The Czech Republic, the Swiss Federal Tribunal had an opportunity to discuss an alleged waiver in a BIT, specifically in Article 8, para. 7 of the Dutch-Czech BIT. That provision stipulates that the decision of the arbitral tribunal "shall be final and binding upon the parties to the dispute". ${ }^{170}$ In reliance on the interpretation rules in the Vienna Convention on the Law of Treaties ("VCLT") as codification of customary international law because it was not directly applicable, the Court came to the same result as in commercial arbitrations with similar wording and held that the waiver was invalid. ${ }^{171}$ It considered that the "final and binding" language did not rule out a remedy such as annulment which was said to be limited to "the most severe defects". ${ }^{172}$ It also found support in Article 53, para. 1 of the ICSID Convention, which provides that ICSID awards are "binding on the parties", a characteristic that does not rule out the availability of an annulment mechanism. While it is conceivable that the parties may contractually waive their right to seek annulment of the award in terms that fulfil the form requirements of Article 192, para. 1 of the PILA, ${ }^{173}$ IIAs do normally not contain such express language and thus the application of Article 192, para. 1 PILA to non-ICSID investment arbitrations appears limited.

145 Table 3.1 summarizes all the known investment treaty arbitrations for which an action to set aside has been brought before the Swiss Federal Tribunal. ${ }^{174}$ None of the cases decided thus far concerned a Swiss BIT (and thus, a Swiss party), which is unsurprising given that the seat is often chosen as a neutral venue between the disputing parties. Thus far, the Swiss Federal Tribunal has never upheld an application to annul an investment award, which is in line with its pro-arbitration attitude.

the arbitration agreement or by a subsequent written agreement, exclude any action for annulment in full or limit it to one or the other of the grounds listed in Article 190(2)"). On the waiver of annulment under Swiss law, see generally Kaufmann-Kohler and Rigozzi (2015), pp. 437-447.

${ }^{169}$ Kaufmann-Kohler and Rigozzi (2015), p. 439 (with further references).

${ }^{170}$ Netherlands-Czech Republic BIT (1991), Article 8, para. 7.

${ }^{171}$ Swiss Federal Tribunal decision, Czech Republic v. Saluka Investments BV, decision of 7 September 2006, 4P.114/2006, para. 5.4, ASA Bulletin (2007), 123, 139-143.

${ }^{172}$ Swiss Federal Tribunal decision, Czech Republic v. Saluka Investments BV, decision of 7 September 2006, 4P.114/2006, para. 5.4.2.1, ASA Bulletin (2007), 123, 140-141.

${ }^{173}$ See, for instance, Swiss Federal Tribunal, Lebanon v. France Télécom, decision of 10 November 2005, 4P.98/2005, ASA Bulletin (2006), 98, para. 4 (where the parties had concluded an agreement in which they, inter alia, consolidated two pending arbitration proceedings, the first under a contract, and the second under the BIT. Such agreement contained a waiver to challenge the jurisdiction of the arbitral tribunal, which the Swiss Federal Tribunal found to constitute a valid waiver agreement pursuant to Article 190, para. 2 of the PILA).

${ }^{174}$ In addition to the annulment cases set out in Table 3.1, the Swiss Federal Tribunal was also seized with a request for revision of an investment treaty award. See Swiss Federal Tribunal, Walter Bau AG (in liquidation) v. The Kingdom of Thailand, decision of 23 July 2012, 4A_570/2011, available at http://www.swissarbitrationdecisions.com. 


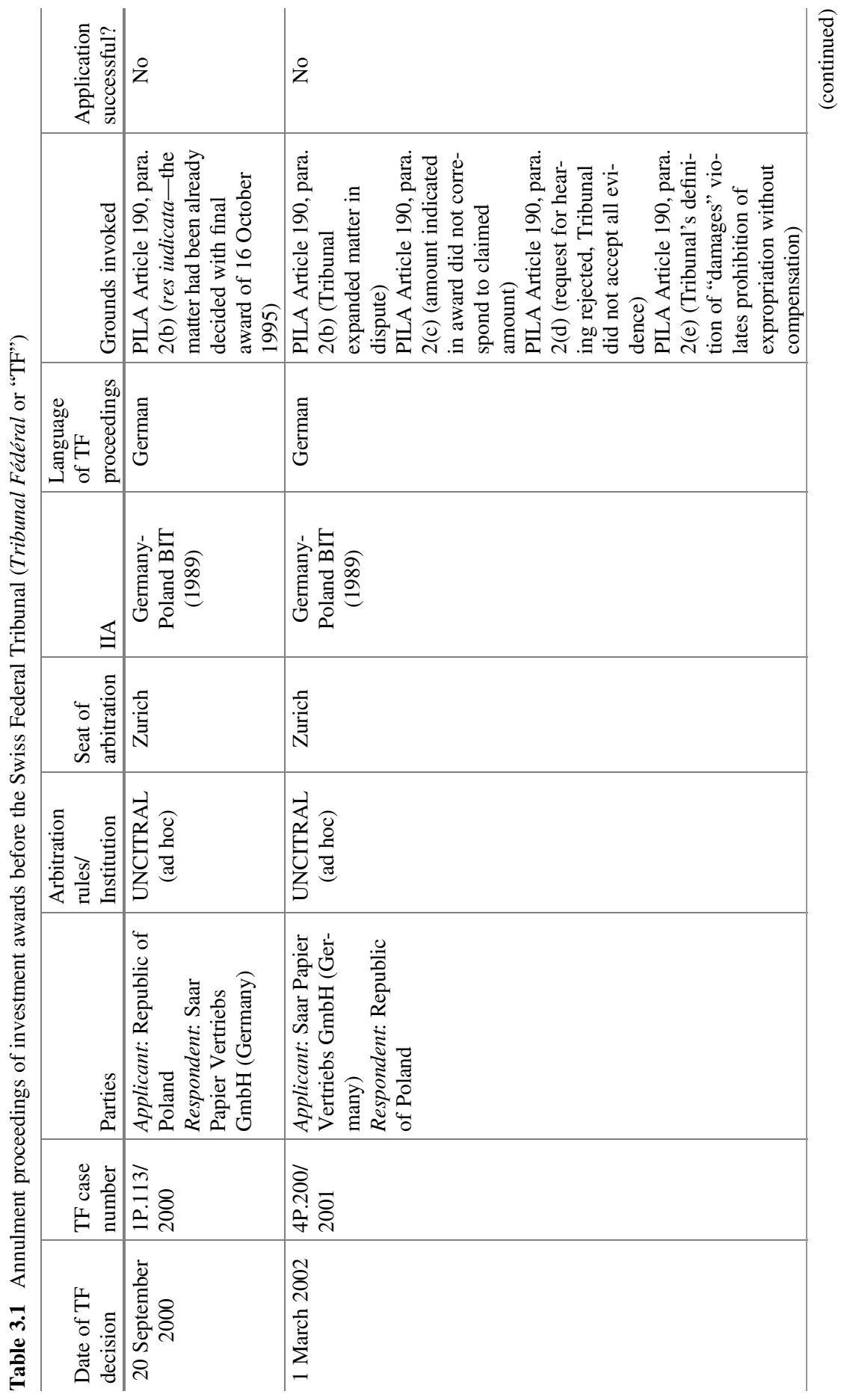




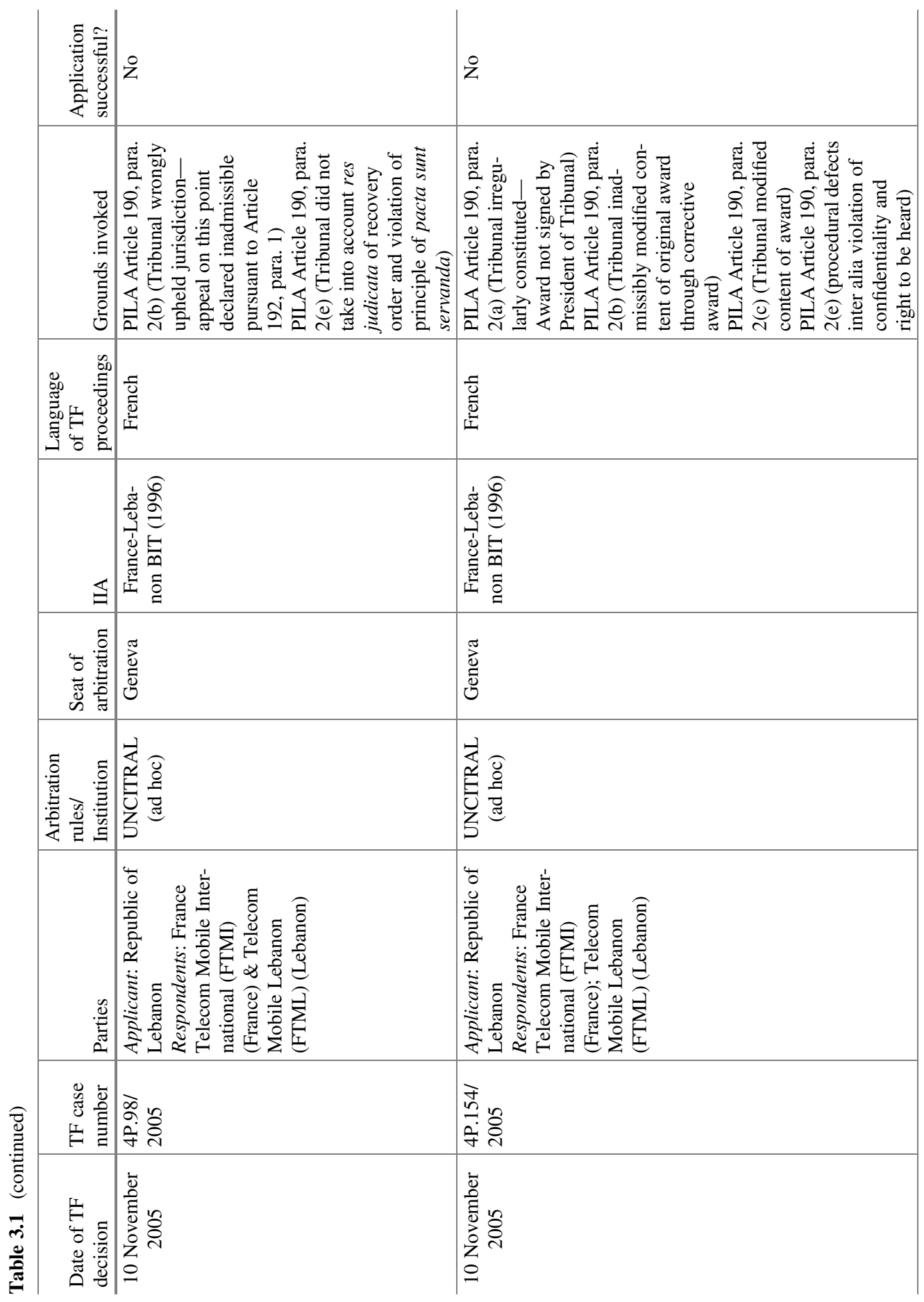




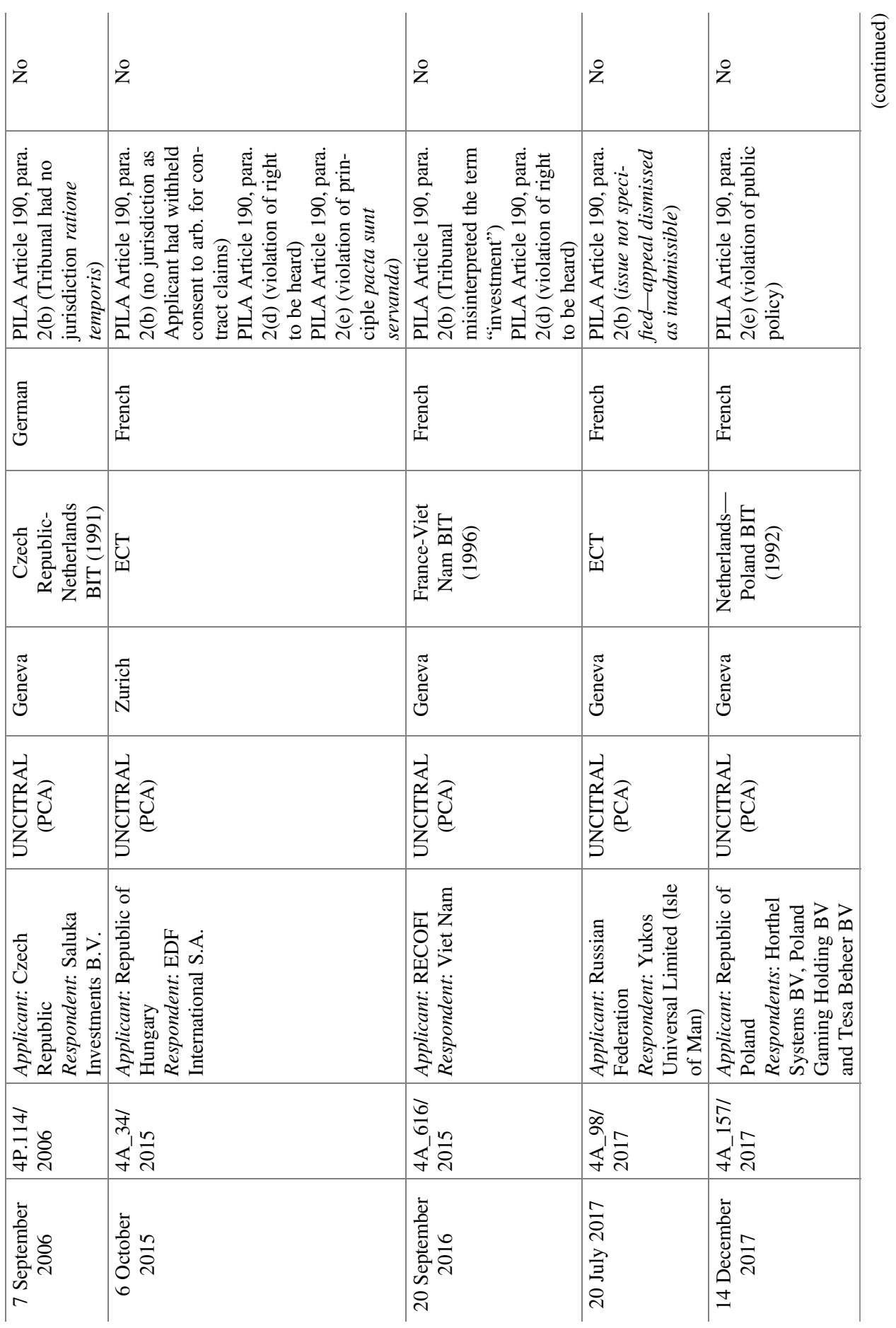


3 The Interplay Between Investor-State Arbitration and Domestic Courts in the...

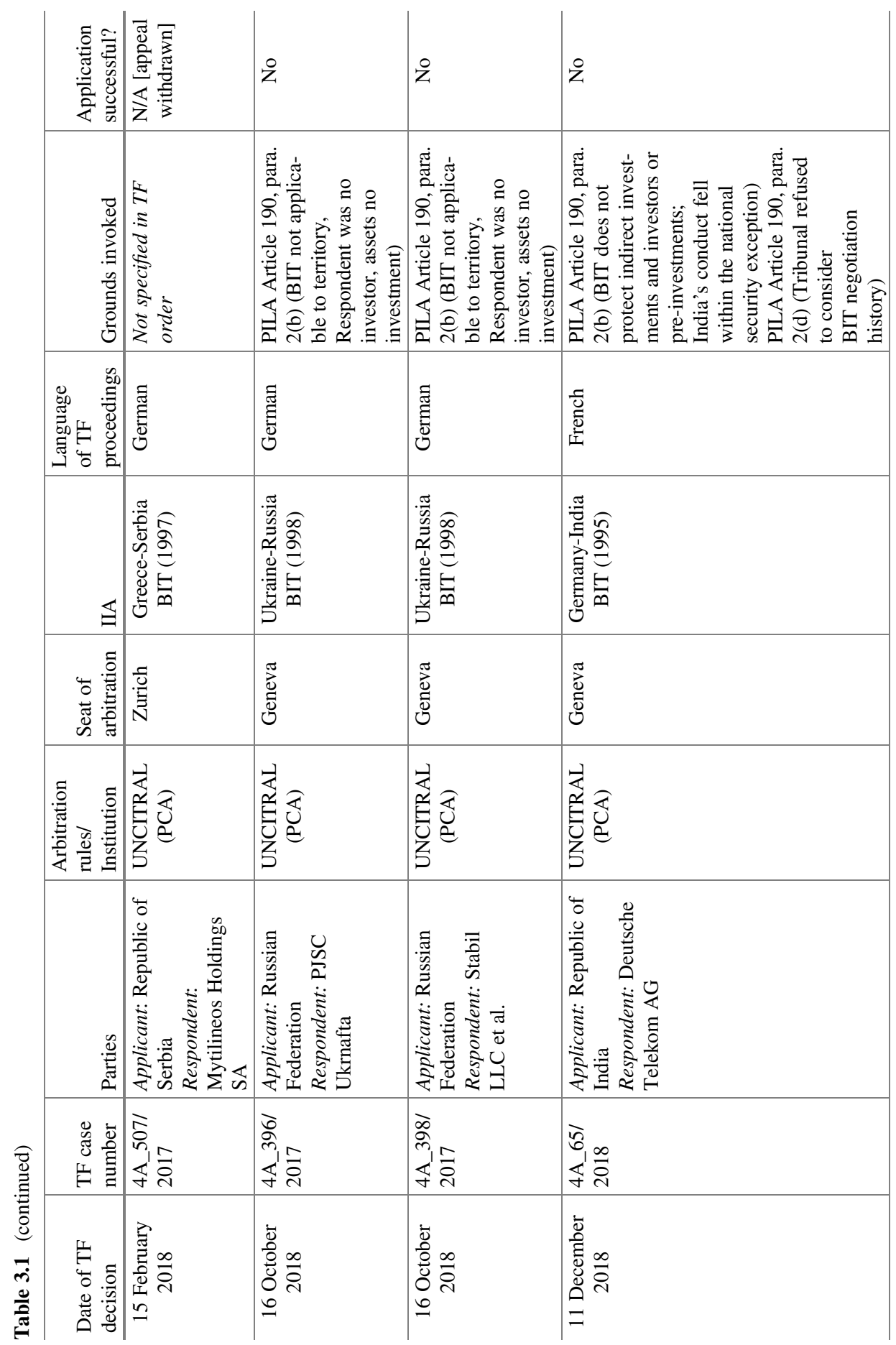




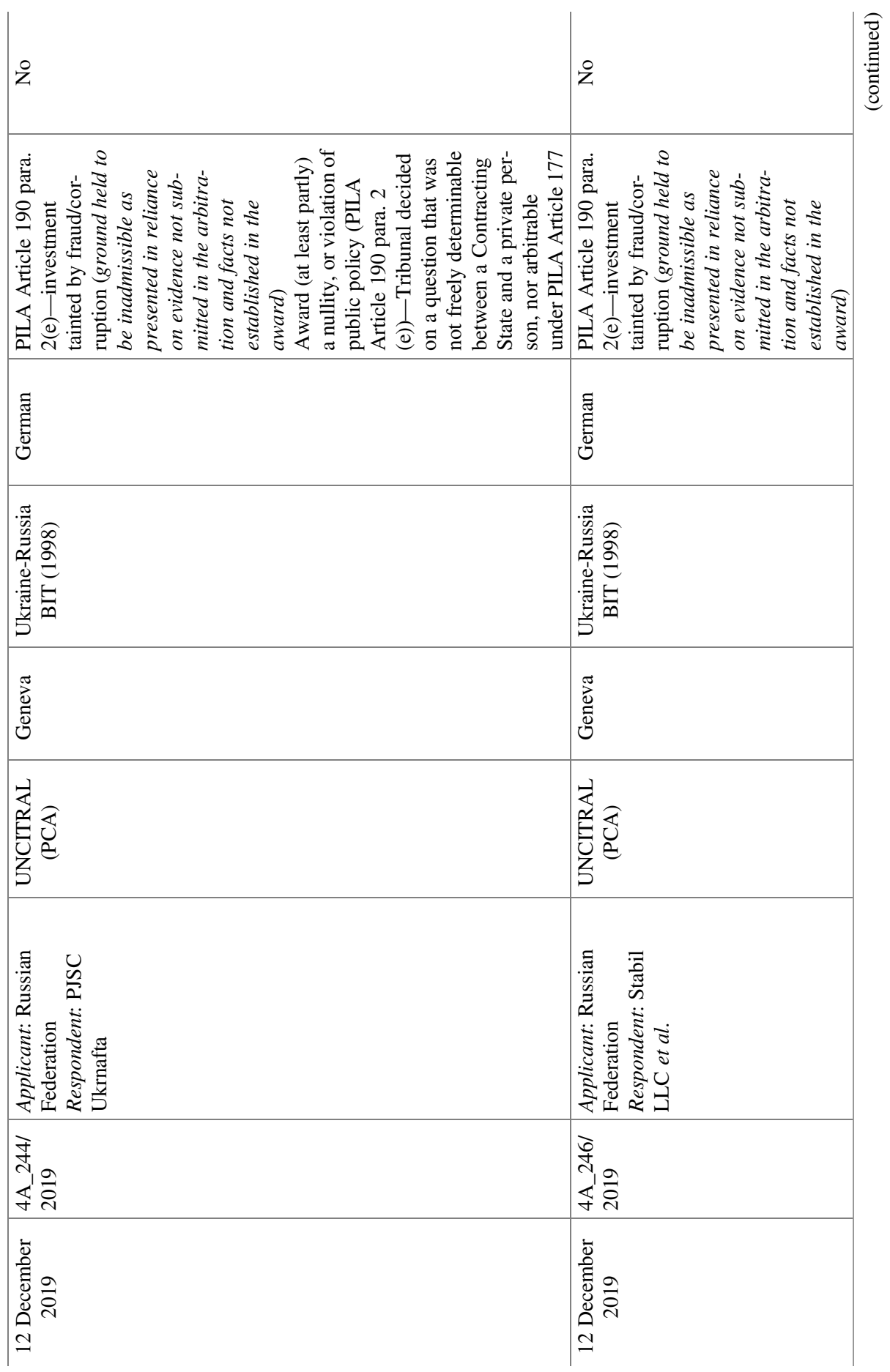




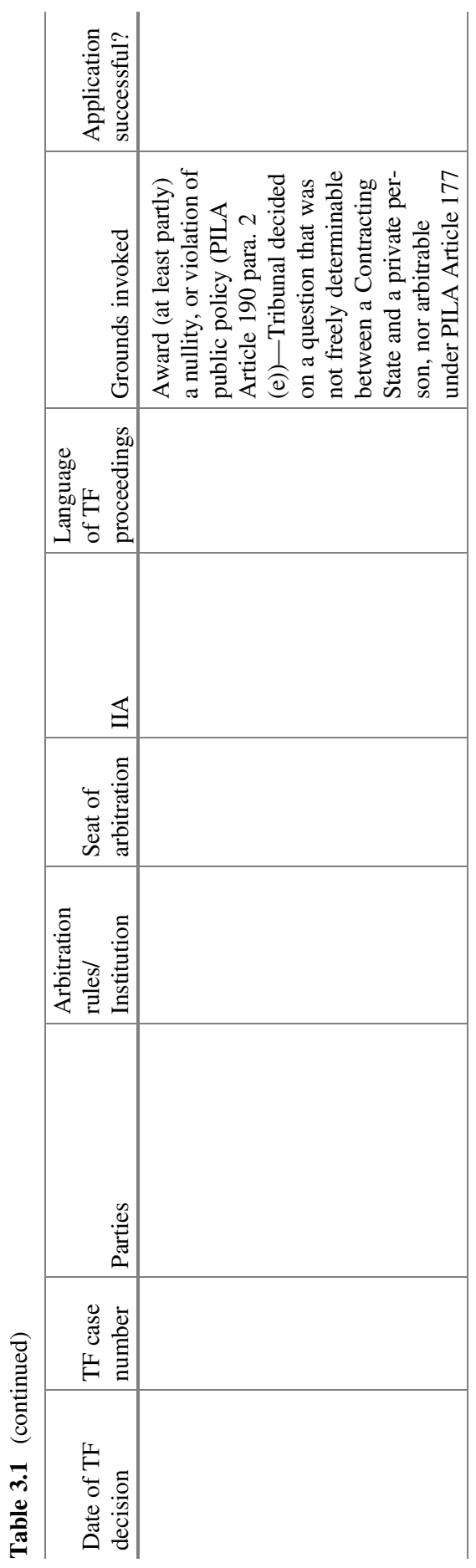




\subsubsection{Enforcement}

The last situation in which a domestic court may be faced with investment arbitration matters is in connection with a request to enforce an arbitral award. ${ }^{175}$ Once again, the role of courts in the enforcement of ICSID and non-ICSID awards must be distinguished.

Pecuniary obligations imposed by awards issued in ICSID arbitrations benefit from a special treatment in the sense that they require no enforcement under the NYC (on which see below). Indeed, pursuant to Article 54, para. 1 of the ICSID Convention, ICSID Contracting States, including Switzerland, are committed to enforce the award "as if it were a final judgment of a court in that State". ${ }^{176}$ This means that a domestic court or authority before which execution (as opposed to enforcement) of an ICSID award is sought is restricted to ascertaining the award's authenticity ${ }^{177}$ and to any execution requirements and defenses under national law (e.g. the defense of prior payment of the award). This is yet another feature of the "self-contained" ICSID Convention system.

Enforcement of non-ICSID awards is governed by the national law of the State where enforcement is sought and by the NYC.

In Switzerland, one must distinguish between awards rendered in and outside of Switzerland. For the former, the position under Swiss law is quite unique in comparative law terms, given that arbitral awards rendered in Switzerland are assimilated to court judgments without any further formalities. ${ }^{178}$ Where the parties have validly waived the right to challenge the award in accordance with Article 192, para. 1 PILA (which is an unlikely scenario in investment treaty arbitration, as observed above), the losing party will be able to rely on the grounds for refusal of

\footnotetext{
${ }^{175}$ See generally Reinisch (2018), pp. 797-822.

${ }^{176}$ Furthermore, Under Article 54, para. 2 ICSID Convention, “[e]ach Contracting State shall notify the Secretary-General of the designation of the competent court or other authority for this purpose and of any subsequent change in such designation". Switzerland has designated different courts for each canton. See Designations of Courts or Other Authorities Competent for the Recognition and Enforcement of Awards Rendered Pursuant to the Convention (Article 54, para. 2 of the Convention), ICSID/8-E, available at https://icsid.worldbank.org/en/Documents/icsiddocs/ICSID\%208Contracting $\% 20$ States $\% 20$ and $\% 20$ Measures $\% 20$ Taken $\% 20$ by $\% 20$ Them $\% 20$ for $\% 20$ the $\% 20$ Pur pose $\% 20$ of $\% 20$ the $\% 20$ Convention.pdf.

${ }^{177}$ Schreuer et al. (2009), p. 1148.

${ }^{178}$ Thus, if an award orders the payment of monies, it will be sufficient for the creditor to issue an order to pay in the context of debt collection proceedings and then to obtain the lifting of a possible objection to such order. The debtor will only be able to resist the enforcement of the award by establishing that "the debt has been paid or that its payment has been deferred [after the issuance of the award], or [...] that it is time-barred" (Article 81, para. 1 of the Federal Act on Debt Collection and Insolvency (DEBA) of 11 April 1889). It is possible, but not necessary, to obtain a certificate of enforceability of the award (Article 193, para. 2 PILA). When such a certificate has been issued, the court seized with the debt collection proceedings is bound by it and cannot refuse enforcement on the basis of Article 81, para. 1 DEBA. See Kaufmann-Kohler and Rigozzi (2015), p. 415, footnote 355 .
} 
enforcement under Article V of the NYC, in accordance with Article 192, para. 2 PILA.

150 On the other hand, enforcement in Switzerland of non-ICSID awards rendered outside of Switzerland is subject to the NYC. By providing that "the recognition and enforcement of foreign arbitral awards are governed by the New York Convention of 10 June 1958 on the recognition and enforcement of foreign arbitral awards" (Article 194 of the PILA), and withdrawing its reciprocity reservation, Switzerland made the recognition and enforcement of all awards rendered outside of Switzerland subject to the NYC, even when they were rendered in a country that is not a Contracting State of the NYC. ${ }^{179}$

151 To be enforceable under the NYC, the decision at issue must be an arbitral award within the meaning of the NYC and, in particular, it must be "foreign", i.e. "made in the territory of a State other than the State where the recognition and enforcement [...] are sought" (Article I, para. 1, NYC). From the point of view of Swiss law, an arbitral award is "foreign" if it emanates from a tribunal whose seat was outside Switzerland. ${ }^{180}$ There will thus normally be no difficulty for courts in determining that non-ICSID investment awards rendered in arbitration seated abroad fulfil this requirement. For the avoidance of doubts, certain IIAs specify that a disputing party may seek enforcement of an arbitration award rendered on the basis of the IIA "under [...] the New York Convention". ${ }^{181}$ Treaties may further stipulate that "[a] claim that is submitted to arbitration under [the IIA] shall be considered to arise out of a commercial relationship or transaction for purposes of Article I of the New York Convention", ${ }^{182}$ which specification is made in light of the fact that Article I, para. 3, of the Convention allows States to make a declaration to the effect that they "will apply the Convention only to differences arising out of legal relationships, whether contractual or not, which are considered as commercial under the national law of the State making such declaration". ${ }^{183}$

152 In reviewing an investment award under the NYC, domestic courts, including Swiss courts, will be bound by the exclusive grounds for non-recognition and non-enforcement listed in Article V of the Convention. Article V NYC includes

\footnotetext{
${ }^{179}$ See Kaufmann-Kohler and Rigozzi (2015), p. 518. In accordance with Article I, para. 3 NYC, "[w]hen signing, ratifying or acceding to this Convention [...] any State may on the basis of reciprocity declare that it will apply the Convention to the recognition and enforcement of awards made only in the territory of another Contracting State". When it acceded to the NYC in 1965, Switzerland made a reciprocity reservation under this provision. The reservation was withdrawn, with effect as of 23 April 1993 (AS/RO 1993, 2439), upon the entry into force of Chapter 12 PILA (and more specifically of its Article 194). Ibid, footnote 615.

${ }^{180}$ Kaufmann-Kohler and Rigozzi (2015), p. 522.

${ }^{181}$ U.S. Model BIT (2012), Article 34, para. 9.

${ }^{182}$ U.S. Model BIT (2012), Article 34, para. 10. See also ECT, Article 26, para. 5(b) providing that "[a]ny arbitration under this Article shall at the request of any party to the dispute be held in a state that is a party to the New York Convention. Claims submitted to arbitration hereunder shall be considered to arise out of a commercial relationship or transaction for the purposes of article I of that Convention."

${ }^{183}$ NYC, Article I, para. 3 (emphasis added).
} 
grounds that relate to the tribunal's jurisdiction, namely the validity of the arbitration agreement, including arbitrability, form, and the parties' capacity to submit to arbitration, as well as grounds covering the fundamental principles of procedure, irregularities in the tribunal's composition, ultra petita awards, and public policy.

Finally, domestic courts may be faced with the application of the rules on immunity of States from execution, which are left intact in the enforcement of both non-ICSID and ICSID awards. ${ }^{184}$ Issues of immunity often arise when alleged State assets located in Switzerland are attached in order to satisfy the award.

Generally speaking, a Swiss court seized with an application to execute an investment treaty award against sovereign States would grant the application if three requirements are met: (1) the State has not acted as a sovereign ("iure imperii") in the legal relationship which underlies the claim giving rise to the award, but has acted as the holder of private rights ("iure gestionis"); (2) the assets targeted by the execution measures are not to be assigned to tasks which are part of the foreign State's duty as a public authority, and are thus not excluded from execution proceedings pursuant to Article 92, para. 1 of the Federal Act on Debt Collection and Insolvency (DEBA); and (3) the transaction out of which the claim against the foreign State arises must have a sufficient connection to Switzerland (in German: "Binnenbeziehung"; in French "rattachement suffisant"). ${ }^{185}$

In the ICSID AF case of Sistem Muhendislik Insaat Sanayi ve Ticaret A.S. v. Kyrgyz Republic, the claimant sought to attach claims held by the International Air Transport Association (IATA), seated in Geneva, against the respondent State for charges for surveillance of national airspace. In a decision of 2011, the Swiss Federal Tribunal rejected an appeal against the lower court's decision that had refused execution on the grounds that the surveillance of national airspace was a sovereign task, and hence de iure imperii. Charges levied for this task were thus exempted from attachments pursuant to Article 92 DEBA. ${ }^{186}$

The Swiss Federal Tribunal's decision of 7 September 2018 concerning the enforcement of an UNCITRAL investment treaty award against Uzbekistan marks a rare instance of the application of the Binnenbeziehung doctrine to an investment treaty award. ${ }^{187}$ In application of this doctrine, the Swiss Federal Tribunal declined to enforce the award against the Republic of Uzbekistan, on the grounds that the underlying dispute presented no "substantial link" with Switzerland. ${ }^{188}$ The Court

\footnotetext{
${ }^{184}$ In the context of the ICSID Convention, this is expressly provided by Article 55, which stipulates that "[n]othing in Article 54 [on recognition and enforcement of ICSID awards] shall be construed as derogating from the law in force in any Contracting State relating to immunity of that State or of any foreign State from execution".

${ }^{185}$ See generally Giroud (2012), pp. 758-766; Radjai and Stirnimann (2013), pp. 1109-1110.

${ }^{186}$ See Swiss Federal Tribunal, A. A.S. v. Etat du Kirghizistan, Office des poursuites de Genève, decision of 23 November 2011, 5A_681/2011, ASA Bulletin (2012), pp. 819-824.

${ }^{187}$ See Swiss Federal Tribunal, A. Limited v. Republic of Uzbekistan, decision of 7 September 2018, 5A_942/2017, available at http://www.swissarbitrationdecisions.com.

${ }^{188}$ For the Swiss Federal Tribunal, "a levy of execution against a foreign state is subject to the prerequisite that the legal relationship in question has a sufficient domestic connection with the
} 
considered that the requirement was a "rule of procedure" imposed by Swiss law, and observed that Article III of the NYC makes it clear that "each signatory state permits arbitral awards to be enforced in line with the procedural requirements of the sovereign territory in which enforcement of the arbitral award is being sought". ${ }^{189}$ The decision of the Federal Tribunal should be viewed in light of the limited scope of review available to it in the attachment proceedings at issue. ${ }^{190}$ Indeed, the Federal Tribunal expressly left open "what findings [it] would reach if it was called to rule upon an appeal from a res judicata decision on the recognition and enforcement of a foreign arbitral award made against a foreign state without limiting the power to review". ${ }^{191} \mathrm{Be}$ that as it may, where enforcement of a foreign award is governed by a treaty such as the NYC, the application of a "substantial link" requirement appears, in the authors' view, incompatible with Switzerland's international obligations under the Convention, which makes no provision for this requirement. Article III NYC deals with procedure in the strict sense of the word and does not allow to add

territory of Switzerland. There must be circumstances present that tie the legal relationship so closely to Switzerland that there is a good justification for proceeding before the Swiss authorities against the foreign state [...]. This prerequisite will, in particular, be considered to be met if the obligation from which the disputed attachment claim is derived was established in Switzerland or was to be performed in Switzerland, or if the foreign state has undertaken some acts in Switzerland by which it established Switzerland as the place of performance. However, it is not sufficient that assets of a foreign state are located in Switzerland or that the claim was the subject of an award by an arbitral tribunal with its seat in Switzerland". See Swiss Federal Tribunal, A. Limited v. Republic of Uzbekistan, decision of 7 September 2018, 5A_942/2017, para. 6.3.2.

${ }^{189}$ Swiss Federal Tribunal, A. Limited v. Republic of Uzbekistan, decision of 7 September 2018, 5A_942/2017, para. 6.3.4. Article III of the NYC provides that: "Each Contracting State shall recognize arbitral awards as binding and enforce them in accordance with the rules of procedure of the territory where the award is relied upon, under the conditions laid down in the following articles. There shall not be imposed substantially more onerous conditions or higher fees or charges on the recognition or enforcement of arbitral awards to which this Convention applies than are imposed on the recognition or enforcement of domestic arbitral awards".

${ }^{190}$ See Swiss Federal Tribunal, A. Limited v. Republic of Uzbekistan, decision of 7 September 2018, 5A_942/2017, paras. 2, 4 and 6.4.4 (review is limited to "arbitrariness" and "pursuant to the consistent jurisprudence of the Federal Tribunal, a decision will not be deemed arbitrary merely because another outcome appears arguable or even more correct. Rather, arbitrary application of the law will only be deemed to have occurred where the challenged decision is manifestly untenable and in clear conflict with the facts, or represents a gross violation of a norm or undisputed legal principle, or runs counter to and offends notions of justice; what is required in this respect is that the decision is found to be arbitrary not merely in terms of its reasoning, but also in terms of its outcome"; "The challenged decision is based on the legal view that the requirement of a sufficient domestic connection will also apply in the context of the New York Convention. The Appellant does not succeed in proving that the Cantonal Court has acted in an arbitrary way in assessing the legal situation in this manner").

${ }^{191}$ Swiss Federal Tribunal, A. Limited v. Republic of Uzbekistan, decision of 7 September 2018, 5A_942/2017, para. 6.4.4. 
requirements (such as the "substantial link" requirement) which ultimately result in expanding the exhaustive list of grounds contained in Article V. ${ }^{192}$

\subsection{State Liability: Investment Tribunals Reviewing Domestic Court Conduct}

This chapter provides an overview of the main instances in which investment tribunals review the conduct of domestic courts for the purposes of establishing a violation of international law. ${ }^{193}$

A State can be held liable for violations of international law incurred as a result of a decision of a national court. Pursuant to Article 4, para. 1, of the ILC Draft Articles on State Responsibility, courts are organs of the State as are its parliament and the government:

The conduct of any State organ shall be considered an act of that State under international law, whether the organ exercises legislative, executive, judicial or any other functions, whatever position it holds in the organization of the State, and whatever its character as an organ of the central Government or of a territorial unit of the State.

Thus, in principle, it is possible for investment treaty tribunals to review whether conduct by State courts can violate international law and specifically the treaty standards contained in the IIA. They do so under the main heading of "denial of justice" (infra at Sect. 3.4.1) as well as under other treaty guarantees (infra at Sect. 3.4.2). One area that has given rise to a number of awards recently deals with court decisions in the field of commercial arbitration (infra a Sect. 3.4.3).

\subsubsection{Denial of Justice}

Typically, domestic court conduct may be reviewed under the "denial of justice" standard, an old institution of customary international law, which is concerned

\footnotetext{
${ }^{192}$ This being so, U.S. courts, for instance, adopt a similar approach when they add a requirement of personal jurisdiction to entertain the enforcement of a foreign award or dismiss actions to enforce foreign awards on forum non conveniens grounds. See In Re: the Arbitration Between Monegasque De Reassurances SAM (Monde Re), v. Nak Naftogaz of Ukraine and State of Ukraine, $311 \mathrm{~F} 3 \mathrm{~d}$ 488 (2d Cir 2002); First Inv. Corp. of Marshall Islands v. Fujian Mawei Shipbuilding, Ltd, 703 F.3d 742, 749-50 (5th Cir. 2012) ("Even though the New York Convention does not list personal jurisdiction as a ground for denying enforcement, the Due Process Clause requires that a court dismiss an action, on motion, over which it has no personal jurisdiction [...]. Congress could no more dispense with personal jurisdiction in an action to confirm a foreign arbitral award than it could under any other statute").

${ }^{193}$ For further references, see Paulsson (2005); Douglas (2014), pp. 867-900; Demirkol (2018).
} 
specifically with the conduct of courts. There is general consensus that denial of justice is one of the sub-elements of the FET standard contained in most IIAs. ${ }^{194}$

A claim for denial of justice may be asserted only after all available means offered by the State's judiciary have been exhausted. The rationale for requiring exhaustion of remedies as a substantive element of a denial of justice is that as long as the domestic legal system is still reviewing the case (within a reasonable timeframe), justice cannot yet be regarded as denied. ${ }^{195}$ Typically, investment tribunals set a demanding test for a showing of denial of justice. So for instance, the ICSID tribunal in Philip Morris v. Uruguay:

\begin{abstract}
As held by one decision, "[a] denial of justice implies the failure of a national system as a whole to satisfy minimum standards." The high standard required for establishing this claim in international law means that it is not enough to have an erroneous decision or an incompetent judicial procedure, arbitral tribunals not being courts of appeal. For a denial of justice to exist under international law there must be "clear evidence of . . . an outrageous failure of the judicial system" or a demonstration of "systemic injustice" or that "the impugned decision was clearly improper and discreditable."196
\end{abstract}

162 Thus, investment treaty tribunals do not acts as an additional appeal level reviewing domestic court rulings on the merits. ${ }^{197}$ Their function "is not to correct errors of domestic procedural or substantive law which may have been committed by the national courts". ${ }^{198}$ To succeed with a claim that the host State courts have denied an investor justice, the investor needs to demonstrate that "the relevant courts refuse[d] to entertain suit, [...] subject[ed] it to undue delay, or [...] administer [ed] justice in a seriously inadequate way". ${ }^{199}$ A misapplication of the law will not suffice, unless it can be shown that such misapplication was "clear and malicious". 200

\footnotetext{
${ }^{194}$ See Demirkol (2018), pp. 33-34 (with further references).

${ }^{195}$ Shany (2007), p. 31.

${ }^{196}$ Philip Morris Brands Sàrl, Philip Morris Products S.A. and Abal Hermanos S.A. v. Oriental Republic of Uruguay (formerly FTR Holding SA, Philip Morris Products S.A. and Abal Hermanos S.A. v. Oriental Republic of Uruguay), ICSID Case No. ARB/10/7, Award, 8 July 2016, paras. 499-500.

${ }^{197}$ The 2015 Indian Model BIT specifies that investor-State arbitral tribunals under the treaty "shall not have the jurisdiction to [...] review the merits of a decision made by a judicial authority of the Parties". See Indian Model BIT (2015), Article 13, para. 5(i).

${ }^{198}$ Liman Caspian Oil BV and NCL Dutch Investment BV v. Republic of Kazakhstan, ICSID Case No. ARB/07/14, Excerpts of Award, 22 June 2010, para. 274.

${ }^{199}$ Robert Azinian, Kenneth Davitian and Ellen Baca v. United Mexican States, Award, 1 November 2009, para. 102 ("A denial of justice could be pleaded if the relevant courts refuse to entertain a suit, if they subject it to undue delay, or if they administer justice in a seriously inadequate way").

${ }^{200}$ Robert Azinian, Kenneth Davitian and Ellen Baca v. United Mexican States, Award, November 2009, para. 103 ("There is a fourth type of denial of justice, namely the clear and malicious misapplication of the law").
} 


\subsubsection{Other International Standards of Protection}

Denial of justice is not the only international law standard that can be breached by domestic courts. IIAs recognize that the State can commit other breaches through its courts that do not amount to denial of justice and for which less stringent criteria apply. ${ }^{201}$ For instance, recent treaties concluded by the EU, such as the CETA, specifically recognize that a fundamental breach of due process in judicial proceedings, manifest arbitrariness and targeted discrimination are wrongful acts independent from denial of justice. ${ }^{202}$

Investment tribunals have entertained claims relating to alleged wrongs committed by domestic courts under a number of different IIA standards. Unlike for denial of justice, a breach of other international IIA obligations does not require exhaustion of local remedies, ${ }^{203}$ unless expressly provided otherwise. Therefore, even the judicial act of a first instance court may give rise to a treaty breach. ${ }^{204}$

In a number of cases, investment tribunals have found that the FET standard protects investors from wrongful treatment by the judiciary aside from cases of denial of justice. ${ }^{205}$ Situations of this kind have included disrespect of due process and procedural propriety, arbitrariness, and obstruction of the investment through abusive proceedings. ${ }^{206}$ In Deutsche Bank v. Sri Lanka, for instance, the ICSID tribunal found that a Supreme Court decision constituted a breach of FET as it was contrary to due process and "issued for political reasons". ${ }^{207}$

Protection against unlawful expropriation has also sometimes been found to cover misconduct by domestic courts. Although, as noted in Tatneft $v$. Ukraine, the prohibition of unlawful expropriation is mainly concerned with the protection of property rights against the government abusing its legislative or executive power and is thus mostly related to administrative and legislative acts, "the issue of whether in addition an act of expropriation can also originate in the judiciary [is] not in principle

\footnotetext{
${ }^{201}$ See Demirkol (2018), p. 28.

${ }^{202}$ See, e.g., CETA, Article 8, para. 10(2), providing that "[a] Party breaches the obligation of fair and equitable treatment referenced in paragraph 1 if a measure or series of measures constitutes: (a) denial of justice in criminal, civil or administrative proceedings; (b) fundamental breach of due process, including a fundamental breach of transparency, in judicial and administrative proceedings; (c) manifest arbitrariness; (d) targeted discrimination on manifestly wrongful grounds, such as gender, race or religious belief; (e) abusive treatment of investors, such as coercion, duress and harassment [...]".

${ }^{203}$ Saipem S.p.A. v. The People's Republic of Bangladesh, ICSID Case No. ARB/05/07, Award, 30 June 2009, para 181.

${ }^{204}$ See Chevron Corporation (USA) and Texaco Petroleum Company (USA) v. The Republic of Ecuador, UNCITRAL, PCA Case No. 34877, Partial Award on the Merits, 30 March 2010, para. 322; Demirkol (2018), p. 29.

${ }^{205}$ See generally Demirkol (2018), pp. 34-39.

${ }^{206} \mathrm{Ibid}$.

${ }^{207}$ See Deutsche Bank AG v. Democratic Socialist Republic of Sri Lanka, ICSID Case No. ARB/09/ 2, Award, 31 October 2012, paras. 478-480.
} 
excluded under interactional law and BIT protection". ${ }^{208}$ The tribunal in Eli Lilly $v$. Canada also noted that "[a]s a matter of broad proposition, [...] it is possible to contemplate circumstances in which a judicial act (or omission) may engage questions of expropriation under NAFTA Article 1110, such as, perhaps, in circumstances in which a judicial decision crystallizes a taking alleged to be contrary to NAFTA Article 1110". ${ }^{209}$ In Middle East Cement v. Egypt, the tribunal found that "though normally, a seizure and auction ordered by the national courts does not qualify as a taking, they can be a 'measure the effects of which would be tantamount to expropriation' if they are not taken 'under due process of law". ${ }^{210}$ The tribunal in Garanti Koza v. Turkmenistan Award held that "a seizure of property by a court as the result of normal domestic legal process does not amount to an expropriation under international law unless there was an element of serious and fundamental impropriety about the legal process". ${ }^{211}$

167 A few tribunals have also examined whether the "full protection and security" standard could encompass protection from domestic courts' misconduct. In Frontier Petroleum v. Czech Republic, the tribunal held that in respect of the acts of the judiciary "full protection and security" means that the State is under an obligation to make a functioning system of courts and legal remedies available to the investor. It observed, however, that "not every failure to obtain redress is a violation of the principle of full protection and security" and "[e]ven a decision that in the eyes of an outside observer, such as an international tribunal, is 'wrong' would not automatically lead to State responsibility as long as the courts have acted in good faith and have reached decisions that are reasonably tenable". ${ }^{212}$

168 Finally, a few IIAs contain a so-called "effective means standard" clause. As noted by the Chevron v. Ecuador I tribunal, provisions of this type are relatively rare. ${ }^{213}$ One such example is Article 10, para. 12, of the ECT, to which Switzerland is a party, which provides as follows:

\footnotetext{
${ }^{208}$ See OAO Tatneft v. Ukraine, UNCITRAL PCA Case No. 2008-8, Award on the Merits, 29 July 2014, paras. 459-461.

${ }^{209}$ Eli Lilly and Company v. The Government of Canada, UNCITRAL, ICSID Case No. UNCT/14/ 2, Award, 16 March 2017, para. 221.

${ }^{210}$ Middle East Cement Shipping and Handling Co. S.A. v. Arab Republic of Egypt, ICSID Case No. ARB/99/6, Award, 12 April 2002, para. 139.

${ }^{211}$ See Garanti Koza LLP v. Turkmenistan, ICSID Case No. ARB/11/20, Award, 19 December 2016, para. 365 .

${ }^{212}$ See Frontier Petroleum Services Ltd. v. The Czech Republic, Final Award, 12 November 2010, para. 273.

${ }^{213}$ Chevron Corporation (USA) and Texaco Petroleum Company (USA) v. The Republic of Ecuador, UNCITRAL, PCA Case No. 34877, Partial Award on the Merits, 30 March 2010, paras. 241-244, finding also that the effective means provision in the U.S.-Ecuador BIT constitutes a lex specialis and not a mere restatement of the law on denial of justice, which entails that a distinct and potentially less-demanding test is applicable under the effective means standard as compared to denial of justice under customary international law.
} 
Each Contracting Party shall ensure that its domestic law provides effective means for the assertion of claims and the enforcement of rights with respect to Investments, investment agreements, and investment authorisations.

According to the Amto v. Ukraine tribunal, the "fundamental criterion" of an "effective means" for the assertion of claims and the enforcement of rights within the meaning of Article 10, para. 12, of the ECT, is "law and the rule of law"; "[t]here must be legislation for the recognition and enforcement of property and contractual rights"; "[a]n effective means of the assertion of claims and the enforcement of rights also requires secondary rules of procedure so that the principles and objectives of the legislation can be translated by the investor into effective action in the domestic tribunals". ${ }^{214}$ The effective means standard was further discussed in the White Industries $v$. India award, which is addressed infra.

\subsubsection{Domestic Court Decisions on Commercial Arbitration}

One particular area in which investment arbitration has been used as a forum for the adjudication of disputes arising out of domestic courts' alleged misconduct concerns national court decisions about the enforcement of arbitration agreements and the annulment or enforcement of arbitral awards in commercial matters under the NYC. ${ }^{215}$ In these instances, investment tribunals have exercised a sort of "supersupervisory" role over domestic courts' conduct relating to commercial arbitration. $^{216}$ These cases further highlight the complex interaction between various dispute resolution mechanisms that may have a bearing on a private party's investment and involve commercial arbitration, domestic courts, and investment arbitration.

As an illustration, in the dispute between Frontier Petroleum and the Czech Republic mentioned earlier, the investment tribunal assessed whether a national court's refusal to enforce an arbitral award under the NYC for reasons of incompatibility with international public policy breached the applicable IIA. The tribunal dismissed the respondent's argument that an investment arbitration tribunal lacks power to review a national court's decision rendered under the NYC. It considered that its role was "to determine whether the refusal of the Czech courts to recognize and enforce the Final Award in full violate[d] Article III(1) of the BIT, i.e., the fair and equitable treatment standard". ${ }^{217}$ It went on to say that "in order to answer this question the tribunal must ask whether the Czech courts' refusal amounts to an abuse

\footnotetext{
${ }^{214}$ Limited Liability Company Amto v. Ukraine, SCC Case No. 080/2005, Final Award, 26 March 2008, p. 52.

${ }^{215}$ See generally Kaufmann-Kohler (2013), pp. 153-174.

${ }^{216}$ Kaufmann-Kohler (2013), p. 154.

${ }^{217}$ Frontier Petroleum Services Ltd. v. The Czech Republic, Final Award, 12 November 2010, para. 525.
} 
of rights contrary to the international principle of good faith" ${ }^{218}$ Recognizing that "States enjoy a certain margin of appreciation in determining what their own conception of international public policy is", ${ }^{219}$ the question, in the tribunal's view, was whether "the decision by the Czech courts [was] reasonably tenable and made in good faith". 220

172 Saipem v. Bangladesh involved the conduct of domestic courts relating to an ICC arbitration seated in the respondent's capital, Dhaka. ${ }^{221}$ During the ICC arbitration, the Bangladeshi courts intervened in several ways, including issuing an injunction restraining Saipem from continuing with the ICC arbitration and revoking the authority of the ICC tribunal. Once the ICC tribunal had nevertheless rendered its award, the courts ruled that, because of the revocation of authority, there "was no award in the eye of the law" which could either be set aside or enforced. ${ }^{222}$ Saipem then initiated ICSID proceedings under the Italy-Bangladesh BIT. The ICSID tribunal held that the Bangladeshi courts had taken measures amounting to unlawful expropriation. ${ }^{223}$ The measures also constituted an abuse of rights under international law ${ }^{224}$ and breached the NYC. ${ }^{225}$

173 The UNCITRAL award in White Industries $v$. India provides a further example of an investment tribunal's review of a decision of national courts relating to a commercial arbitration award. ${ }^{226}$ The investor initially sought enforcement of an ICC award in India. After 9 years of complex litigation involving enforcement and setting aside proceedings (none of which resulted in a determination), White Industries initiated an investment arbitration invoking the Australia-India BIT. ${ }^{227}$ The

\footnotetext{
${ }^{218}$ Frontier Petroleum Services Ltd. v. The Czech Republic, Final Award, 12 November 2010, para. 525 .

${ }^{219}$ Frontier Petroleum Services Ltd. v. The Czech Republic, Final Award, 12 November 2010, para. 527.

${ }^{220}$ Frontier Petroleum Services Ltd. v. The Czech Republic, Final Award, 12 November 2010, para. 527 (emphasis in the original).

${ }^{221}$ Saipem S.p.A. v. The People's Republic of Bangladesh, ICSID Case No. ARB/05/07, Decision on Jurisdiction and Recommendation on Provisional Measures, 21 March 2007 and Award, 30 June 2009. For commentaries on Saipem, see Radicati di Brozolo and Malintoppi (2010), pp. 993-1012; Mourre and Vagenheim (2010), pp. 843-866.

${ }^{222}$ Saipem S.p.A. v. The People's Republic of Bangladesh, ICSID Case No. ARB/05/07, Decision on Jurisdiction and Recommendation on Provisional Measures, 21 March 2007, paras. 26-36.

${ }^{223}$ Saipem S.p.A. v. The People's Republic of Bangladesh, ICSID Case No. ARB/05/07, Award, 30 June 2009, paras. 129, 133, 201-202.

${ }^{224}$ Saipem S.p.A. v. The People's Republic of Bangladesh, ICSID Case No. ARB/05/07, Award, 30 June 2009, paras. 160-161.

${ }^{225}$ Saipem S.p.A. v. The People's Republic of Bangladesh, ICSID Case No. ARB/05/07, Award, 30 June 2009, paras. 167-168, 170.

${ }^{226}$ White Industries Australia Limited v. The Republic of India, UNCITRAL, Final Award, 30 November 2011.

${ }^{227}$ White Industries Australia Limited v. The Republic of India, UNCITRAL, Final Award, 30 November 2011, paras. 3.2.1-3.2.65.
} 
investment treaty tribunal dismissed the claims of expropriation, ${ }^{228}$ FET $^{229}$ and denial of justice. ${ }^{230}$ However, it found that the duration of the enforcement proceedings (which included more than 5 years on the docket of the Supreme Court) amounted to a breach of India's obligation to provide "effective means of asserting claims and enforcing rights". 231

In sum, these and other cases ${ }^{232}$ involving review by investment tribunals of national court decisions in relation to commercial arbitration matters show that States, through their courts, enjoy a level of discretion in the application and interpretation of the applicable legal framework, which is most often the NYC. Most mistakes made in this exercise of application and interpretation of the law will trigger no international responsibility. It is only when the national court's mistake reaches the high threshold of an egregious misconduct that redress may be sought from an international dispute resolution body. ${ }^{233}$

\section{References}

Allen BE, Soave T (2014) Jurisdictional overlap in WTO dispute settlement and investment arbitration. Arbitr Int 30(1):1-58

Bernardini P (2010) ICSID versus non-ICSID investment treaty arbitration. In: FernándezBallesteros MA, Lozano DA (eds) Liber Amicorum Bernardo Cremades. Wolters Kluwer, Alphen aan den Rijn, pp 159-188

Besson S (2016) Droit international public, 3rd edn. Stämpfli Verlag AG, Bern, pp 333-337

Bjorklund AK (2004) Waiver and the exhaustion of local remedies rule in NAFTA jurisprudence. In: Weiler T (ed) NAFTA investment law and arbitration: past issues, current practice, future prospects. BrilllNijhoff, Leiden, pp 253-286

Bonnitcha J, Skovgaard Poulsen LN, Waibel M (2017) The political economy of the investment treaty regime. Oxford University Press, Oxford, pp 84-85

Brauch MD (2017) Exhaustion of local remedies in international investment law, Best Practices Series. International Institute for Sustainable Development, Winnipeg, pp 7-12

Bronckers M (2015) Is Investor-State Dispute Settlement (ISDS) superior to litigation before domestic courts?An EU view on bilateral trade agreements. J Int Econ law 18:655-677

Brower CN, Goodman REM (1991) Provisional measures and the protection of ICSID jurisdictional exclusivity against municipal proceedings. ICSID Rev Foreign Invest Law J 6 (2):431-461

\footnotetext{
${ }^{228}$ White Industries Australia Limited v. The Republic of India, UNCITRAL, Final Award, 30 November 2011, Section 12.

${ }^{229}$ White Industries Australia Limited v. The Republic of India, UNCITRAL, Final Award, 30 November 2011, paras. 10.1-10.3.

${ }^{230}$ White Industries Australia Limited v. The Republic of India, UNCITRAL, Final Award, 30 November 2011, Section 10.4.

${ }^{231}$ See in particular White Industries Australia Limited v. The Republic of India, UNCITRAL, Final Award, 30 November 2011, Section 11.

${ }^{232}$ See, e.g. ATA Construction, Industrial and Trading Company v. The Hashemite Kingdom of Jordan, ICSID Case No. ARB/08/2, Award, 18 May 2010.

${ }^{233}$ See Radicati di Brozolo and Malintoppi (2010), pp. 993-1012.
} 
Collins L (1992-III) Provisional and protective measures in international litigation. In: Recueil des Cours 218, vol 234. Martinus Nijhoff, Leiden, p 99

Crawford J (2008) Treaty and contract in investment arbitration. Arbitr Int 24(3):351-374

Crawford J, Grant TD (2007) Local remedies, exhaustion of. In: Wolfrum R (ed) Max Planck Encyclopedia of Public International Law. Oxford University Press, Oxford

De Luca A (2016) Direct Effect of EU's Investment Agreements and the Energy Charter Treaty in the EU, Rivista Eurojus.it, 15 November 2016, Available at http://rivista.eurojus.it/direct-effectof-eus-investment-agreements-and-the-energy-charter-treaty-in-the-eu/

Delaume GR (1983) ICSID arbitration and the courts. Am J Int Law 77(4):784-803

Delaume GR (1984) ICSID arbitration in practice. Int Tax Bus Lawyer 2:58-78

Demirkol B (2018) Judicial acts and investment treaty arbitration. Cambridge University Press, Cambridge

Dodge WS (2006) Investor-state dispute settlement between developed countries: reflections on the Australia-United states free trade agreement. Vanderbilt J Transnational Law 39(1):1-37

Dolzer R, Schreuer CH (2012) Principles of international investment law, 2nd edn. Oxford University Press, Oxford, p 235

Douglas Z (2004) The hybrid foundations of investment treaty arbitration. Br Yearb Int Law 74 (1):151-289

Douglas Z (2012) The international law of investment claims. Cambridge University Press, Cambridge, pp 98-99

Douglas Z (2014) International responsibility for domestic adjudication: denial of justice deconstructed. Int Comp Law Q 63(4):867-900

Fix-Fierro H, López-Ayllón S (1997) The impact of globalization on the reform of the state and the law in Latin America. Houston J Int Law 19(3):785-801

Friedland PD (1986) Provisional measures and ICSID arbitration. Arbitr Int 2(4):335-357

García-Castrillón CO (2016) Spain and investment arbitration: the renewable energy explosion, investor-state arbitration series, Paper No. 17, November 2016. Centre for International Governance Innovation, Waterloo

David Gaukrodger (2018) Appointing authorities and the selection of arbitrators in investor-state dispute settlement: an overview, OECD Consultation Paper, March 2018, paras. 205-222, Available at http://www.oecd.org/investment/investment-policy/ISDS-Appointing-AuthoritiesArbitration-March-2018.pdf

Gil R (2009) ICSID provisional measures to enjoin parallel domestic litigation. World Arbitr Mediation Rev 3(4-5):353-602

Ginsburg T (2005) International substitutes for domestic institutions: bilateral investment treaties and governance. Int Rev Law Econ 25(1):107-123

Giroud S (2012) Enforcement against state assets and execution of ICSID awards in Switzerland: how Swiss courts deal with immunity defences. ASA Bull 30(4):758-766

Hanessian G, Duggal K (2017) The final 2015 Indian Model BIT: is this the change the world wishes to see? ICSID Rev Foreign Invest Law J 32(1):216-226

Hathaway OA, McElroy S, Solow SA (2012) International law at home: enforcing treaties in U.S. Courts. Yale J Int Law 37(1):51-106

Hepburn J (2009) India agrees new investment treaty text with Colombia, Belarus And Taiwan, advancing some of its key concerns such as partial exhaustion and human rights [Updated], IAReporter, (1 January 2019)

Hober K, Eliasson N (2018) Review of non-ICSID awards by National Courts. In: Yannaca-Small $\mathrm{K}$ (ed) Arbitration under international investment agreements, a guide to the key issues, 2nd edn. Oxford University Press, Oxford, pp 759-796

Johnson L (2015) Aligning Swiss investment treaties with sustainable development: an assessment of current policy coherence and options for future action. Columbia Centre on Sustainable Investment, New York, $\mathrm{p} 14$

Kaiser K (2013) Treaties, direct applicability. In: Wolfrum R (ed) Max Planck encyclopedia of public international law, 2nd edn. Oxford University Press, Oxford 
Kalderimis D (2016) The authority of investment treaty tribunals to issue orders restraining domestic court proceedings. ICSID Rev Foreign Invest Law J 31(3):549-575

Kaufmann-Kohler G (2013) Commercial arbitration before international courts and tribunals reviewing abusive conduct of domestic courts. Arbitr Int 29(2):153-174

Kaufmann-Kohler G, Rigozzi A (2015) International arbitration law and practice in Switzerland. Oxford University Press, Oxford, p 57

Kaufmann-Kohler G, Antonietti A, Potestà M (2018) Interim relief in investment arbitration. In: Yannaca-Small K (ed) Arbitration under international investment agreements, a guide to the key issues, 2nd edn. Oxford University Press, Oxford, pp 647-649

Kjos HE (2016) International law through the National Prism: the role of domestic law and jurisprudence in shaping international investment law. In: Reinisch A, Footer ME, Binder C (eds) International law and .... Select proceedings of the European Society of International Law. Hart Publishing, Oxford, p 84

Kriebaum U (2009) Local remedies and the standards for the protection of foreign investment. In: Binder C, Kriebaum U, Reinisch A, Wittich S (eds) International investment law for the 21st century. Oxford University Press, Oxford, pp 417-462

Mourre A, Vagenheim A (2010) Some comments on denial of justice in public and private international law after Loewen and Saipem. In: Fernández-Ballesteros MA, Lozano DA (eds) Liber Amicorum Bernardo Cremades. Wolters Kluwer, Alphen aan den Rijn, pp 843-866

Muchlinski P (2009) Diplomatic protection of foreign investments. In: Binder C, Kriebaum U, Reinisch A, Wittich S (eds) International investment law for the 21st century. Oxford university Press, Oxford, p 345

Ortiz AL, Ugalde-Revilla P, Chinn C (2016) The role of national courts in ICSID arbitration. In: Baltag C (ed) ICSID Convention after 50 years: unsettled issues. Wolters Kluwer, Alphen aan den Rijn, pp 329-362

Parra AR (1993) The practices and experience of ICSID in ICC, Conservatory and Provisional Measures in International Arbitration, ICC Publication No. 519, pp 37-44

Paulsson J (2005) Denial of justice in international law. Cambridge University Press, Cambridge

Pohl J, Mashigo K, Nohen A (2012) Dispute settlement provisions in international investment agreements: a large sample survey, OECD working papers on international investment, 2012/ 02. OECD Publishing, Paris, p 14

Porterfield M (2015) Exhaustion of local remedies in investor-state dispute settlement: an idea whose time has come? Yale J Int Law 41:1-12

Puig S (2013) Investor-state tribunals and constitutional courts: the Mexican Sweeteners Saga. Mexican Law Rev 5(2):199-243

Radicati di Brozolo L, Malintoppi L (2010) Unlawful interference with international arbitration by national courts of the seat in the aftermath of Saipem v. Bangladesh. In: Fernández-Ballesteros MA, Lozano DA (eds) Liber Amicorum Bernardo Cremades. Wolters Kluwer, Alphen aan den Rijn, pp 993-1012

Radjai N, Stirnimann FX (2013) Investment arbitration. In: Arroyo M (ed) Arbitration in Switzerland - the practitioner's guide: commentary. Wolters Kluwer, Alphen aan den Rijn, pp 1049-1112

Ranjan P, Anand P (2017) The 2016 model Indian bilateral investment treaty: a critical deconstruction. Northwest J Int Law Bus 38(1):1-55

Reinisch A (2018) Enforcement of investment treaty awards. In: Yannaca-Small K (ed) Arbitration under international investment agreements, a guide to the key issues, 2nd edn. Oxford University Press, Oxford, pp 797-822

Scherer M, Heiskanen V, Moss S (2009) Domestic review of investment treaty arbitration: the Swiss experience. ASA Bull 27(2):256-279

Schreuer CH (2004) Travelling the BIT route: of waiting periods, umbrella clauses and forks in the road. J World Invest Trade 5(2):231-256

Schreuer CH (2005) Calvo's grandchild: the return of local remedies in investment arbitration. Law Pract Int Courts Tribunals 4(1):1-17 
Schreuer CH (2010) Interaction of international tribunals and domestic courts in investment law. In: Contemporary issues in international arbitration and mediation: the fordham papers, vol 4. Brill Nijhoff, Leiden, pp 71-94

Schreuer CH, Malintoppi L, Reinisch A, Sinclair A (2009) The ICSID Convention-a commentary, 2nd edn. Cambridge University Press, Cambridge

Shany Y (2007) Regulating jurisdictional relations between national and international courts. Oxford University Press, Oxford

Sornarajah M (2010) The international law on foreign investment. Cambridge University Press, Cambridge, p 221

Spiermann O (2009) Premature treaty claims. In: Binder C, Kriebaum U, Reinisch A, Wittich S (eds) International investment law for the 21 st century. Oxford University Press, Oxford, pp 463-489

Tietje C, Baetens F (2014) The Impact of Investor-State-Dispute Settlement (ISDS) in the transatlantic trade and investment partnership, Study prepared for the Minister for Foreign Trade and Development Cooperation and the Ministry of Foreign Affairs of the Netherlands, p 95

Wegen G, Markert L (2010) Food for thought on fork-in-the-road - a clause awakens from its hibernation. In: Zeiler G, Welser I et al (eds) Austrian yearbook on international arbitration, vol 2010, pp 269-292

Open Access This chapter is licensed under the terms of the Creative Commons Attribution 4.0 International License (http://creativecommons.org/licenses/by/4.0/), which permits use, sharing, adaptation, distribution and reproduction in any medium or format, as long as you give appropriate credit to the original author(s) and the source, provide a link to the Creative Commons licence and indicate if changes were made.

The images or other third party material in this chapter are included in the chapter's Creative Commons licence, unless indicated otherwise in a credit line to the material. If material is not included in the chapter's Creative Commons licence and your intended use is not permitted by statutory regulation or exceeds the permitted use, you will need to obtain permission directly from the copyright holder. 